\title{
The Impact of Juvenile Conviction on Human Capital and Labor Market Outcomes
}

\author{
Limor Golan, Rong Hai, and Hayley Wabiszewski
}

This article documents the long-term relationship among juvenile conviction, occupational choices, employment, wages, and recidivism. Using data from the National Longitudinal Survey of Youth 1997 (NLSY97), we document that youth convicted at or before age 17 have a lower full-time employment rate and lower wage growth rate even after 10 years in the labor market. Merging the NLSY97 with occupational characteristics data from the Occupational Information Network $\left(\mathrm{O}^{*} \mathrm{NET}\right)$, we show that youth with a juvenile conviction are less likely to be employed in occupations that have a high on-the-job training requirement and that these occupations have higher wages and wage growth. Accumulated occupation-specific work experience, general experience, and education are important for explaining the gaps in wage and recidivism between youth with and without a juvenile conviction. Our results highlight the important role of occupational choices as a human capital investment vehicle through which juvenile crimes have a longterm impact on wages and recidivism. (JEL K42, I24, J2, J3)

Federal Reserve Bank of St. Louis Review, First Quarter 2022, 104(1), pp. 41-69.

https://doi.org/10.20955/r.104.41-69

\section{INTRODUCTION}

In this article, we document the empirical relationship among juvenile conviction, education, adult labor market occupational choices, employment, wages, and recidivism. Although several studies have shown that juvenile adjudication is associated with lower formal educational attainment and an increased likelihood of dropping out of high school, no existing study examines human capital accumulation through on-the-job (OTJ) training.

Our data are from the National Longitudinal Survey of Youth 1997 (NLSY97) and the Occupational Information Network (O*NET). NLSY97 is a longitudinal survey that follows the lives of a sample of American youth born between 1980-84. It provides detailed information on each individual's convictions and incarcerations over time as well as the age and date of the first time the individual had an interaction with the correctional system. It also collects detailed information on each individual's history of employment, occupations, and wages. Finally, it has information on each

Limor Golan is a professor at Washington University in St. Louis and a research fellow at the Federal Reserve Bank of St. Louis. Rong Hai is an assistant professor at the University of Miami. Hayley Wabiszewski is a PhD candidate at Washington University in St. Louis.

(c) 2022, Federal Reserve Bank of St. Louis. The views expressed in this article are those of the author(s) and do not necessarily reflect the views of the Federal Reserve System, the Board of Governors, or the regional Federal Reserve Banks. Articles may be reprinted, reproduced, published, distributed, displayed, and transmitted in their entirety if copyright notice, author name(s), and full citation are included. Abstracts, synopses, and other derivative works may be made only with prior written permission of the Federal Reserve Bank of St. Louis. 
individual's education, age, gender, race, and measures of cognitive ability. Also, the $\mathrm{O}^{\star} \mathrm{NET}$ data survey provides detailed information on job requirements for and the characteristics of each occupation. Matching the $\mathrm{O}^{\star}$ NET job requirement data to the NLSY97 data, we are able to analyze the impact of a juvenile conviction on occupational choices, which have long-term consequences on wages.

Using the NLSY97 and $\mathrm{O}^{\star}$ NET data, we first document that youth with juvenile adjudications have worse educational outcomes. We then show that juvenile convictions are associated with a lower full-time employment rate, even after controlling for ability, education, and general work experience. We also find that individuals who had a juvenile adjudication are less likely to be employed in occupations with high-OTJ-training requirements. We also show that the wage gap between youth with and without a juvenile conviction can be explained by the differences in accumulated occupation-specific work experience, general work experience, education, and ability. We analyze wage growth over a 10 -year period of employment and find that a juvenile conviction still reduces the wage growth rates even after controlling for education and occupation-specific work experience. Finally, we document a juvenile conviction to be a strong predictor of the likelihood of adult incarceration.

We do find race and gender differences both in the effects of a juvenile conviction and in the above outcomes. For women, having a juvenile conviction does not have a statistically significant effect on the overall employment probability, but it reduces the probability of full-time employment. For men, having a juvenile conviction reduces both the overall employment probability and the full-time employment probability. In addition, male Black workers are less likely to be employed in all specifications; this finding is consistent with findings in the literature (see Ritter and Taylor, 2011). Moreover, Black workers are less likely to be employed in occupations with high training requirements, even after controlling for test scores, education, and experience. This finding is consistent with the findings in Golan, James, and Sanders (2019). Among women, however, once we control for test scores, the coefficient on the Black race dummy becomes statistically insignificant. This finding is true for wages as well. These findings are consistent with the differences in labor force participation of and selection into the labor market for Black and White women (see Neal, 2004). For Hispanic men and women, the negative effects on outcomes either lose statistical significance or become positive once we account for the differences in test scores.

While our results are suggestive regarding the effects of a juvenile conviction on education, employment, occupational choices, and recidivism, it highlights the rich dynamic relationship among youth crime and labor market choices and outcomes (including occupational choices). We argue that a juvenile conviction reduces the probability of future employment in occupations with high-OTJ-training requirements and that this is an important channel through which youth crime interacts with labor market outcomes. Specifically, this channel helps to generate a long-term impact of youth crime on labor market outcomes and it also acts as a cost that affects a youth's decision to commit crime ex ante in a forward-looking model with crimes.

Our article relates to three strands of the literature. First, our article contributes to the literature on juvenile crime and human capital investment. These existing studies primarily focus on schooling as the measure of human capital investment and find that (i) juvenile arrest/adjudication reduces schooling and (ii) school enrollment reduces future crimes. Regarding (i), Kirk and Sampson (2013) and Aizer and Doyle (2015) both find that juvenile arrest, adjudication, or incarceration reduces the probability of high school graduation. Kirk and Sampson (2013) further show that juvenile arrest 
reduces the likelihood of four-year college enrollment conditional on high school graduation. Litwok (2015) supports this result, finding that automatic expungement of juvenile conviction records-unconditionally-increases the probability of college attendance and graduation. Evidence for (ii) in Lochner (2004) shows that high school graduates are less likely than high school dropouts to be incarcerated in their 20s. Similarly, Merlo and Wolpin (2015) find that attending school at age 16 reduces the probability of committing a crime at age 19 .

Second, our article relates to the literature on juvenile crime and labor market outcomes (see Western, Kling, and Weiman, 2001, for a survey). ${ }^{1}$ Litwok (2015) shows that automatic expungement of juvenile criminal records increases an individual's average income in their late 20s. Imai and Krishna (2004) estimate a dynamic discrete choice model of criminal behavior where forwardlooking youth make decisions about whether to commit a crime. The authors show that policies that reduce future labor market punishment for committing a crime lead youth to commit more crime ex ante. Nagin and Waldfogel (1995) look at the impact of conviction at ages 17 and 18 on labor market outcomes at age 19 of young British offenders and find mixed results. They find that conviction status decreases job stability, via more weeks unemployed, a decrease in job duration, and an increase in the number of jobs ever held, but increases weekly earning. Western and Beckett (1999) analyze youth incarceration between the ages of 15 and 22 and its impact on future employment using the NLSY79, finding a long-lasting decrease in employment that does not decay with time. Using NLSY97 data, Apel and Sweeten (2010) find that youth incarceration has a persistent negative impact on formal employment, driven mostly by an increased probability and duration of labor force non-participation. They find that incarceration reduces annual income and that this income gap widens over time.

Third, our article also relates to the literature that investigates the relationship between juvenile crime and future recidivism. This literature is vast, especially in criminology. Nagin and Paternoster (1991), Nagin and Land (1993), and Nagin, Farrington, and Moffitt (1995) evaluate the change in criminal behavior over the life cycle and find that participating in crime early in the life cycle increases the likelihood of participating in crime in the future as social and professional relationships deteriorate. Paternoster, Brame, and Farrington (2001) find some evidence that variation in the propensity to commit crimes as an adult can be attributed to differences in individual criminal behavior established during adolescence as opposed to processes that occur during adulthood. Several studies in economics also evaluate this relationship. Levitt (1998) shows deterrence is empirically more important than incapacitation in reducing crime, particularly in the case of property crimes. Aizer and Doyle (2015) find that individuals on the margin of juvenile incarceration who are incarcerated are significantly more likely to recidivate as adults, especially for serious crimes, relative to those who are not incarcerated. Indeed, Bayer, Hjalmarsson, and Pozen (2009) explore the peer effects of juvenile incarceration on juvenile recidivism and find that there are significant peer effects that increase the probability of recidivism for crimes in which an individual already has experience.

\section{DATA AND BASIC ANALYSIS}

\subsection{Data}

The data are compiled from NLSY97 and O*NET. NLSY97 is a longitudinal survey that follows the lives of a sample of American youth born between 1980-84. 
NLSY97 collects information on each individual's criminal behavior, arrests, convictions, and incarceration in each survey round; it also has information regarding the age and date of the first time the individual interacted with the correctional system. We construct an indicator variable of juvenile convictions that equals 1 if and only if the individual was convicted at least once before age 18. NLSY97 also asks individuals to report their monthly incarceration status. We define an individual as incarcerated in the corresponding year if the individual was incarcerated at least one month of the year.

We obtain a complete weekly history for each individual on their employment status and the number of jobs worked. We also have complete weekly information on the occupation, hours worked, and hourly wage for every job the individual worked, as well as the job starting date and job ending date, over the period 1997 to 2013 . We aggregate the weekly information into annual information. We define an individual as employed if their average weekly hours worked in the reference year is more than or equal to 10 hours; we define an individual as full-time employed if their average weekly hours worked is more than or equal to 30 hours. The number of years an individual has worked can be observed from the start and end dates of each job. An individual's main job in the reference year is characterized by the occupation the individual worked in for the most hours in the year. We focus on the hourly wage of the individual's main job. In addition to hourly wage levels, we also look at wage growth over 10 years; this variable is constructed using the percentage change in an individual's hourly wage in their 11th working year (when their number of years worked is 10) versus their 1st working year (when their number of years worked is 0 ). All wage data are in 2000 dollars.

NLSY97 also provides us information on an individual's age, race, education, year of graduation, and Armed Services Vocational Aptitude Battery (ASVAB) test score. We classify educational attainment into five categories: high school dropout (i.e., no high school diploma and no General Educational Development certificate [GED]), GED, high school graduate, associate college degree, and four-year college degree or higher.

We merge NLSY97 data with $\mathrm{O}^{*}$ NET data based on each employed individual's occupation. The $\mathrm{O}^{\star} \mathrm{NET}$ data include detailed job requirements and characteristics for each occupation. Specifically, $\mathrm{O}^{*} \mathrm{NET}$ asks questions regarding the amount of OTJ training required to perform the job. OTJ training includes apprenticeships, internships, and other supervised experiences. For each occupation, we obtain an OTJ-training intensity variable that documents the percentage of the jobs in that occupation that require more than one month of OTJ training, ranging from 0 percent to 100 percent. We merge this variable with each individual's occupation in the NLSY97 data. Average OTJ-training intensity increases with a worker's education level. In particular, in our final sample, average OTJtraining intensity is 69 percent among college graduates with a four-year degree or higher, indicating that these college graduates are employed in occupations where 69 percent of the jobs require at least one month of OTJ training. The average OTJ-training intensities are 65 percent, 58 percent, 57 percent, and 54 percent for individuals with an associate degree, with a high school diploma, with a GED, or that are a high school dropout, respectively. We say an individual is employed in a high-OTJ-training occupation if the percentage of jobs in that occupation that require one month of OTJ training is higher than the sample median level (i.e., 62 percent in our sample). Examples of low-OTJ-training occupations include parking lot attendants, dining room and cafeteria attendants, and bartender helpers. Examples of high-OTJ-training occupations include mechanics, installers, repairers, electricians, and first-line supervisors/managers of construction and production 


\section{Table 1}

\section{Key Variables by Gender}

\begin{tabular}{lcc} 
& Men & Women \\
\hline Juvenile conviction & 0.079 & 0.038 \\
\hline Less than a high school diploma/GED & 0.088 & 0.076 \\
\hline GED & 0.120 & 0.087 \\
\hline High school graduate & 0.552 & 0.498 \\
\hline Associate college degree & 0.052 & 0.069 \\
\hline Four-year college degree or higher & 0.188 & 0.270 \\
\hline Employment & 0.869 & 0.786 \\
\hline Full-time employment (among employed workers) & 0.668 & 0.589 \\
\hline Employed in high-OTJ-training occupation & 0.555 & 0.431 \\
\hline Years worked & 4.663 & 4.160 \\
\hline Years worked in high-OTJ-training occupation & 2.657 & 1.873 \\
\hline Hourly wage (\$) & 13.059 & 11.488 \\
\hline Change in wage over 10 years worked (\%) & 88.504 & 78.227 \\
\hline Incarceration & 0.027 & 0.005 \\
\hline Race = Black & 0.153 & 0.155 \\
\hline Race = Hispanic & 0.124 & 0.116 \\
\hline Age & 25.575 & 25.837 \\
\hline ASVAB score & 0.470 & 0.484 \\
\hline
\end{tabular}

SOURCE: NLSY97.

workers. High-OTJ-training occupations allow for more human capital accumulation post school and have higher wage growth.

The original NLSY97 data have 8,984 respondents. We drop the observations with no information on the highest degree of education or the year when the individual left school. We also drop observations with missing juvenile conviction, ASVAB, or race information. We only keep observations starting from the year the individual enters the labor market (after obtaining the highest degree of education).

\subsection{Summary Statistics}

In this section, we discuss summary statistics of our data. Because men and women have very different patterns of human capital accumulation and crime behaviors over the life cycle, we present summary statistics as well as analysis results for men and women separately.

Table 1 presents the mean values of key variables used in our analysis. In our sample, the average juvenile conviction rate is 7.9 percent for men and 3.8 percent for woman. In terms of educational outcomes for men, 8.8 percent are high school dropouts, 12 percent have a GED, 55.2 percent are high school graduates, 5.2 percent have an associate college degree, and the remaining 18.8 percent have a four-year college degree or higher. In terms of educational outcomes for women, 7.6 percent 


\section{Figure 1}

\section{Educational Outcomes for Those with and without a Juvenile Adjudication}
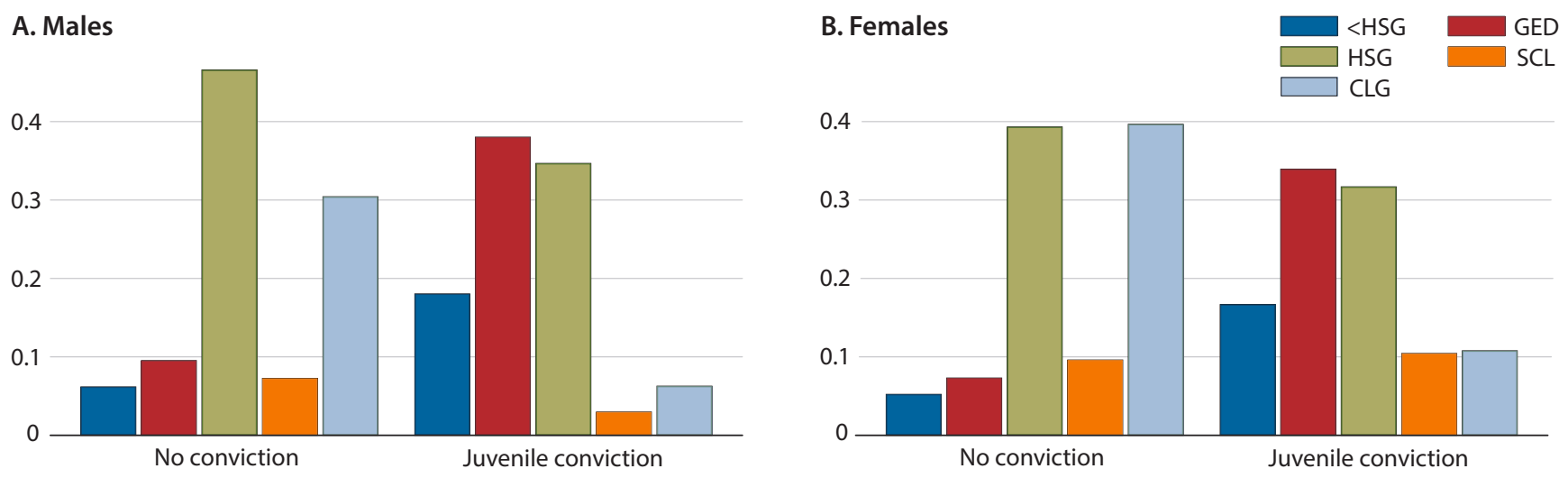

NOTE: $<$ HSG, less than a high school diploma and no GED; HSG, high school graduate; CLG, four-year college degree or higher; and SCL, associate college degree.

SOURCE: NLSY97.

are high school dropouts, 8.7 percent have a GED, 49.8 percent are high school graduates, 6.9 percent have an associate college degree, and the remaining 27 percent have a four-year college degree or higher. Figure 1 plots the distribution of educational outcomes by juvenile conviction status for men and women separately. Compared with men without a juvenile conviction, men with a juvenile conviction are more likely to drop out of high school or have a GED and are less likely to have a four-year college degree or higher. Similar patterns hold for women.

Next, we discuss the outcome variables on labor market employment, occupation, and wages. For men, the employment rate is 86.9 percent and the full-time employment rate is slightly lower, 66.8 percent; the average number of years worked in our sample period is 4.66 years; and 55.5 percent worked in high-OTJ-training occupations, with an average of 2.66 years worked in those occupations. For women, the employment rate is 78.6 percent and the full-time employment rate is 58.9 percent; the average number of years worked in our sample period is 4.16 years; and only 43.1 percent worked in high-OTJ-training occupations, with an average of 1.87 years worked in those occupations. Figure 2 plots the employment rate by age for individuals with and without a juvenile conviction for men and women seperately. There is a large employment gap among men based on their juvenile conviction status, and the gap increases over age as the employment patterns for men with and without juvenile convictions diverge over time. The employment gap also exists for women, but the size of the gap is much smaller and the time trend is less clear than they are for men.

For employed men, the average hourly wage is $\$ 13.06$ (in 2000 dollars) and the average wage growth rate over 10 years worked is 88.5 percent. For employed women, the average hourly wage is $\$ 11.49$ and the average wage growth rate over 10 years worked is 78 percent. Figure 3 plots the average hourly wages by age based on juvenile conviction status for men and women separately. Similar to employment patterns seen in Figure 2, Figure 3A shows that men have a clear widening of the wage gap based on conviction status. The gap starts out relatively small at age 19: Men with a juvenile conviction earn an average hourly wage of $\$ 7.85$ compared with $\$ 8.63$ for those without 


\section{Figure 2}

\section{Employment Rates for Those with and without a Juvenile Adjudication}

\section{A. Males}

Probability of employment

1.0

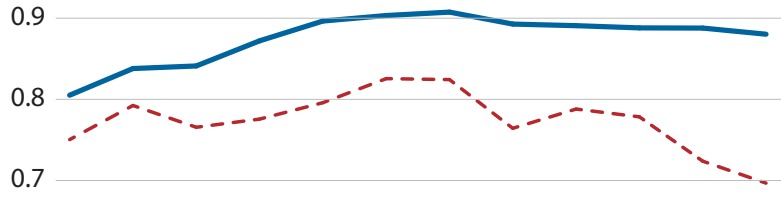

0.6

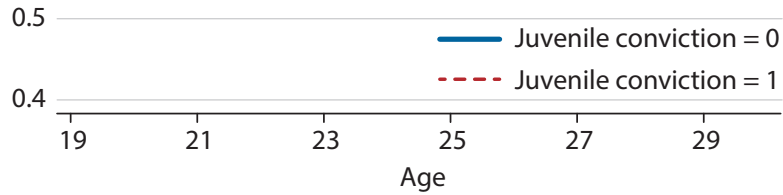

B. Females

Probability of employment

1.0

0.9

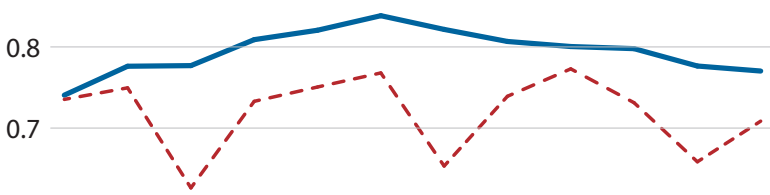

0.6

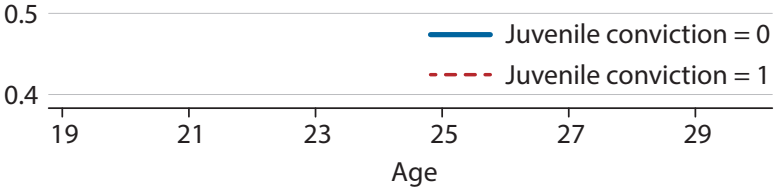

SOURCE: NLSY97.

\section{Figure 3}

\section{Wages for Those with and without a Juvenile Adjudication}
A. Males
B. Females

Hourly wage

20

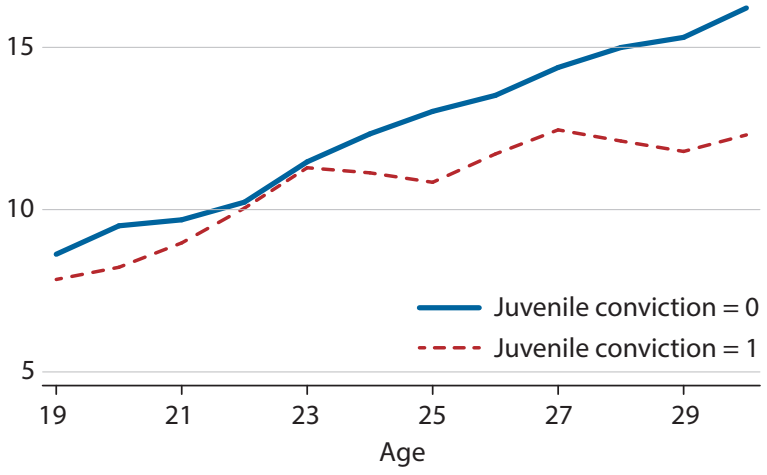

Hourly wage

20

Juvenile conviction $=0$

- - - Juvenile conviction $=1$

15

10

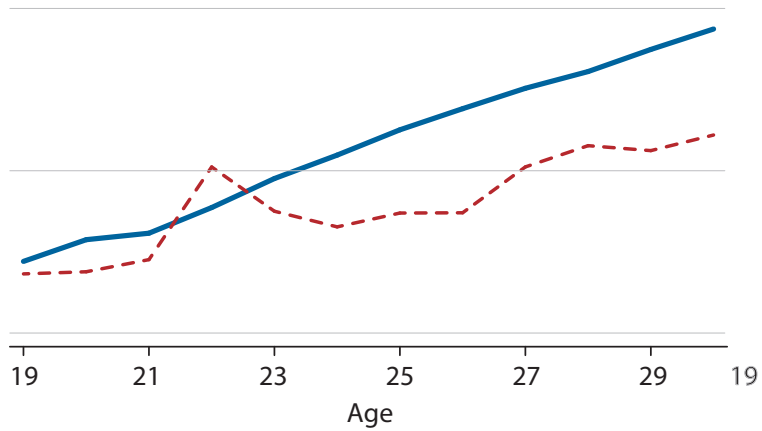

SOURCE: NLSY97. 


\section{Table 2}

\section{Key Variables by Occupation Categories}

\begin{tabular}{lcc} 
& Low OTJT & High OTJT \\
\hline Hourly wage (\$) & 10.071 & 14.161 \\
\hline Change in wage over 10 years worked (\%) & 59.709 & 101.298 \\
\hline Less than a high school diploma/GED & 0.091 & 0.042 \\
\hline GED & 0.116 & 0.078 \\
\hline High school diploma & 0.585 & 0.473 \\
\hline Associate college degree & 0.050 & 0.074 \\
\hline Four-year college degree or higher & 0.158 & 0.333 \\
\hline ASVAB score & 0.443 & 0.543 \\
\hline
\end{tabular}

NOTE: OTJT, on-the-job training.

\section{Figure 4}

\section{Adulthood Incarceration Rates for Those with and without a Juvenile Adjudication}

\section{A. Males}

Probability of incarceration

$0.20 \longrightarrow$ Juvenile conviction $=0$

- - - - Juvenile conviction $=1$
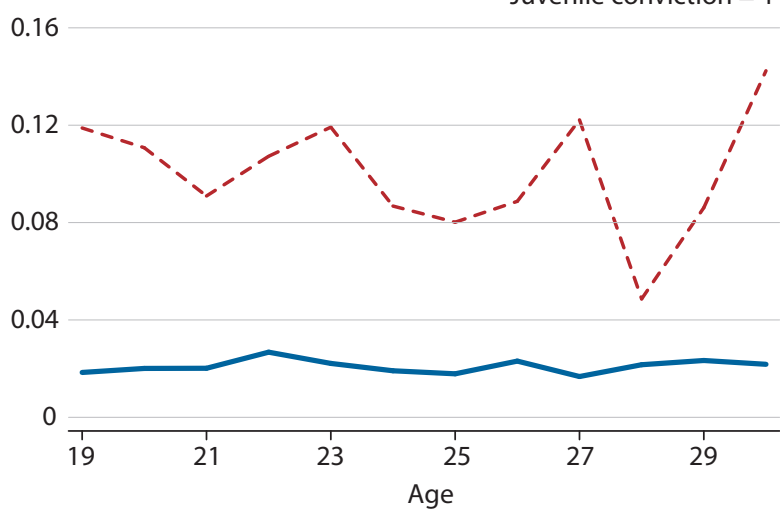

B. Females

Probability of incarceration

0.20

- Juvenile conviction $=0$

- - - - Juvenile conviction $=1$

0.16

0.12

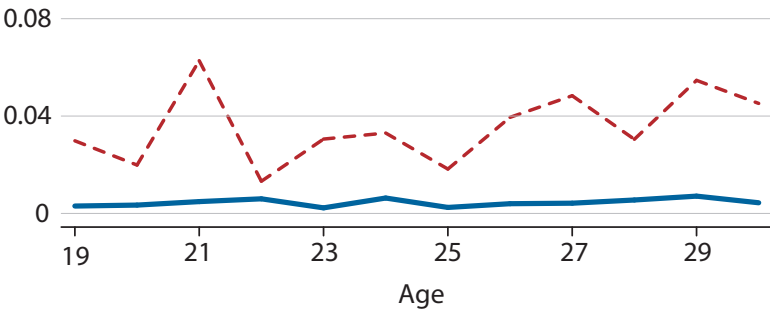

SOURCE: NLSY97.

a juvenile conviction, for a wage gap of $\$ 0.78$. By age 30 , the gap increases over five-fold, to $\$ 3.91$, with average hourly wages of $\$ 12.30$ and $\$ 16.21$, respectively. The hourly wage gap for women has a similar trend: It increases from $\$ 0.39$ at age 19 to $\$ 3.27$ by age 30 .

Table 2 reports the average worker characteristics for high- and low-OTJ-training occupations separately. Both hourly wages and the wage growth rate are lower in low-OTJ-training occupations than in high-OTJ-training occupations. Average hourly wages are \$10.07 in low-OTJ-training occupations and \$14.16 in high-OTJ-training occupations. The average 10-year wage growth rates 
are 60 percent and 101 percent in low- and high-OTJ-training occupations, respectively. Regarding the education levels of workers in low-OTJ-training occupations, 9.1 percent are high school dropouts, 11.6 percent have a GED, 58.5 percent are high school graduates, 5 percent have an associate college degree, and the remaining 15.8 percent have a four-year college degree or higher. Of the workers in high-OTJ-training occupations, 4.2 percent are high school dropouts, 7.8 percent have a GED, 47.3 percent are high school graduates, 7.4 percent have an associate college degree, and the remaining 33.3 percent have a four-year college degree or higher. The average ASVAB score is 0.443 in low-OTJ-training occupations and 0.543 in high-OTJ-training occupations.

Finally, we discuss the adulthood crime outcomes measured by an incarceration indicator variable. As shown in Table 1, the average incarceration rates are 2.7 percent and 0.5 percent for men and women, respectively, and the average age of men and women is about 26 over our sample period. Figure 4 presents the probability of incarceration by juvenile conviction status by age for men and women separately. Individuals with a juvenile conviction are more likely to be incarcerated during adulthood than individuals without a juvenile conviction. This is suggestive evidence that a juvenile conviction predicts adult recidivism. The effects of a juvenile conviction on adulthood incarceration exist both for men and women, but the magnitude is larger for men.

\section{CONCEPTUAL FRAMEWORK AND EMPIRICAL STRATEGY}

\subsection{Conceptual Framework}

Our conceptual framework is a dynamic model of human capital accumulation and crime behaviors. Heterogeneous individuals are forward-looking and make decisions on schooling, employment, occupational choices, and crime behaviors. Firms are also forward-looking and make decisions on occupation-specific job offers that differ in wages and OTJ-training requirements based on observed worker characteristics (also see the framework in Gayle and Golan, 2012). High-OTJtraining occupations incur higher training costs presently but also have higher future productivity growth if the employment relationship continues. Human capital investment in such a framework takes the form of education and post-school occupation-specific OTJ-training investment. Finally, the model allows for past choices as well as the returns to accumulated human capital and criminal capital to affect current choices (Merlo and Wolpin, 2015, and Mancino, Navarro, and Rivers, 2016).

In this model, a juvenile conviction can have a long-lasting impact on a youth's human capital accumulation, labor market outcomes, and future criminal activity through three potential channels. The first channel is through changing an individual's schooling by increasing the psychic costs of schooling and reducing college admission probabilities. A juvenile conviction affects a youth's psychic cost of schooling because interactions with the juvenile justice system can disrupt the youth's schooling activities (Kirk and Sampson, 2013; Aizer and Doyle, 2015; and Litwok, 2015) and harm the youth's mental health (Kashani et al., 1980, and Forrest et al., 2000). Youth with a record may find it hard to be re-enrolled if schooling is disrupted. College admission probabilities may also be reduced because schools may be unwilling to admit juveniles with a conviction record.

The second channel is through changing a youth's post-school human capital accumulation, as measured by accumulated work experience in occupations with different OTJ-training requirements. On one hand, youth with a juvenile record may have less incentive to invest in post-school human capital accumulation because juvenile corrections encourage the accumulation of "criminal 
capital" (Bayer, Hjalmarsson, and Pozem, 2009) and reduce the psychic cost of future incarceration. On the other hand, a potential employer with asymmetric information may be less likely to offer them jobs and less likely to offer them jobs with higher OTJ-training requirements, because the employer anticipates these individuals have higher probabilities of quitting the job and committing crimes in the future.

The last and third channel through which a juvenile conviction has a long-lasting effect is the dynamic interaction between human capital investment and crime behaviors over time. As noted with the previous two channels, individuals with a juvenile record are likely to have lower human capital investment and hence lower future wages and wage growth. Lower wages and wage growth increase the likelihood of future crime activities by reducing the opportunity cost of going to jail and leaving the labor force. As a result, youth with a juvenile record have a higher probability of recidivism, which, in turn, reduces their ex ante incentive to invest in human capital and decreases firms' ex ante willingness to offer them good jobs. The state dependence between past behaviors and current choices further reinforces such interactions. These dynamic interactions between human capital investment and crime behavior exacerbate the negative impact of a juvenile conviction over time. Another factor that affects the correlations between a juvenile record and the outcomes discussed above is unobserved heterogeneity that affects both the likelihood of having a criminal record early on and the likelihood of high educational attainment, stability in the labor market, selection into high OTJ-training occupations, and high wages. However, in the empirical analysis below we are unable to quantify separately unobserved heterogeneity and state dependence.

\subsection{Empirical Strategy}

The preceding figures show considerable differences in educational attainment, employment, wages, and adult incarceration between individuals with and without a juvenile conviction. These differences are representative of an agglomeration of observable and unobservable differences between the two groups aside from juvenile conviction status. To begin sorting out the effects of the differences in the compositions of the two groups and the effect of juvenile conviction status, we next present regression results for outcome variables of interest, including educational outcomes, employment, occupational choices, wages, and adult incarceration. As evidenced by Figures 1 to 4, age is an important determinant of these outcomes. There are also important differences in the racial makeup of each group. Other important omitted variables that are correlated with both juvenile conviction and the outcome variables of interest include educational attainment, individual ability or skills, and job market experience. For example, if individuals without juvenile adjudication have better skills and more education on average, both of which make them more employable, then the coefficient on juvenile adjudication will be biased downward. It is therefore important to control for these confounding variables when analyzing the effect of juvenile conviction status on the relevant outcome variables.

In this section we use the following regression model to conduct our analysis:

$$
y_{i, t}=\beta \cdot \text { JuvenileConviction }_{i}+X_{i, t} \gamma+\epsilon_{i, t},
$$

where $y_{i, t}$ is the outcome variables of interests, including educational outcomes, employment, occupational choices, wages, and adulthood incarceration. JuvenileConviction is an indicator variable that equals 1 if the youth had been convicted at least once before age $18 . X_{i, t}$ is a vector that includes 
Table 3

The Effects of a Juvenile Conviction on Male Educational Outcomes: Less Than a High School Diploma or GED

(1)

\begin{tabular}{lcc}
\hline Juvenile conviction & $\begin{array}{c}0.069^{* * *} \\
(0.0124)\end{array}$ & $\begin{array}{c}0.033^{* * *} \\
(0.0086)\end{array}$ \\
\hline Race = Black & $\begin{array}{c}0.047^{* * *} \\
(0.0090)\end{array}$ & $\begin{array}{c}-0.009 \\
(0.0069)\end{array}$ \\
\hline Race = Hispanic & $\begin{array}{c}0.049^{* * *} \\
(0.0094)\end{array}$ & $\begin{array}{c}0.005 \\
(0.0070)\end{array}$ \\
\hline ASVAB score & & $-0.246^{* * *}$ \\
\hline & & $(0.0512)$ \\
ASVAB score squared & & $0.101^{*}$ \\
\hline Mean value & 0.091 & $(0.0532)$ \\
\hline Observations & 2,646 & 0.091 \\
\hline Pseudo $R^{2}$ & 0.040 & 2,646 \\
\hline NOTE: Marginal effects; standard errors are in parentheses. ${ }^{*} p<0.10$, \\
*** $p<0.05,{ }^{* * *} p<0.01$.
\end{tabular}

Table 4

The Effects of a Juvenile Conviction on Male Educational Outcomes: Four-Year College Degree or Higher

\begin{tabular}{|c|c|c|}
\hline & $(1)$ & $(2)$ \\
\hline Juvenile conviction & $\begin{array}{l}-0.360^{* * *} \\
(0.0634)\end{array}$ & $\begin{array}{l}-0.272^{* * *} \\
(0.0557)\end{array}$ \\
\hline Race $=$ Black & $\begin{array}{l}-0.217^{* * *} \\
(0.0278)\end{array}$ & $\begin{array}{l}0.013 \\
(0.0286)\end{array}$ \\
\hline Race $=$ Hispanic & $\begin{array}{l}-0.165^{* * *} \\
(0.0291)\end{array}$ & $\begin{array}{l}-0.033 \\
(0.0297)\end{array}$ \\
\hline ASVAB score & & $\begin{array}{l}0.742^{* * *} \\
(0.1446)\end{array}$ \\
\hline ASVAB score squared & & $\begin{array}{c}0.012 \\
(0.1316)\end{array}$ \\
\hline Mean value & 0.239 & 0.239 \\
\hline Observations & 2,646 & 2,646 \\
\hline Pseudo $R^{2}$ & 0.047 & 0.241 \\
\hline $\begin{array}{l}\text { NOTE: Marginal effects; s } \\
{ }^{* *} p<0.05,{ }^{* * *} p<0.01 \text {. }\end{array}$ & d errors are ir & eses. ${ }^{*} p<0.10$ \\
\hline
\end{tabular}

individual variables such as race, education, and work experience, and $\epsilon_{i, t}$ is an error term. We use the logit model when the dependent variable is a dummy variable (including employment, occupational choices, and educational outcomes), and we report the marginal effects associated with each regression variable. We perform OLS analysis when the outcome variables are continuous variables such as log wages and wage growth.

\section{RESULTS}

\subsection{Juvenile Conviction and Educational Outcomes}

In this section, we investigate the effects of a juvenile conviction on educational outcomes. Educational outcomes are central to accumulation of human capital after individuals complete their education because it is a strong determinant of labor market attachment, occupational sorting, and earnings growth. Consistent with the existing literature, we also find that a juvenile conviction increases the probability of dropping out of high school and decreases the probability of having a four-year college degree or higher.

Starting with the results for men, Column 1 of Table 3 shows that men with a juvenile conviction are 6.9 percentage points more likely to drop out of high school. Race also affects the probability of dropping out of high school, with Black men 4.7 percentage points and Hispanic men 4.9 percentage points more likely to drop out. Once we control for the ability measures (Column 2), the effect of a juvenile conviction on men is reduced to 3.3 percentage points and the effects of the two race dummies lose statistical significance. Column 1 of Table 4 shows that a juvenile conviction reduces the 
Table 5

\section{The Effects of a Juvenile Conviction on Female Educational Outcomes: Less Than a High School Diploma or GED}

(1)

\begin{tabular}{lcc}
\hline Juvenile conviction & $\begin{array}{c}0.064^{* * *} \\
(0.0148)\end{array}$ & $\begin{array}{c}0.014^{* *} \\
(0.0066)\end{array}$ \\
\hline Race $=$ Black & $0.029^{* * *}$ & $-0.014^{* * *}$ \\
& $(0.0084)$ & $(0.0043)$ \\
\hline Race $=$ Hispanic & $0.031^{* * *}$ & -0.005 \\
\hline ASVAB score & $(0.0090)$ & $(0.0036)$ \\
\hline ASVAB score squared & & $-0.146^{* * *}$ \\
\hline Mean value & & $(0.0384)$ \\
\hline Observations & 0.067 & 0.047 \\
\hline Pseudo $R^{2}$ & 2,781 & $0.0320)$ \\
\hline NOTE: Marginal effects; standard errors are in parentheses. ${ }^{*} p<0.10$, \\
** $p<0.05,{ }^{* * *} p<0.01$. & & 2,781 \\
\hline
\end{tabular}

Table 6

\section{The Effects of a Juvenile Conviction on Female Educational Outcomes: Four-Year College Degree or Higher}

\begin{tabular}{lcc} 
& $(1)$ & $(2)$ \\
\hline Juvenile conviction & $-0.418^{* * *}$ & $-0.341^{* * *}$ \\
& $(0.0929)$ & $(0.0931)$ \\
\hline Race $=$ Black & $-0.213^{* * *}$ & 0.020 \\
& $(0.0261)$ & $(0.0298)$ \\
\hline Race $=$ Hispanic & $-0.248^{* * *}$ & $-0.100^{* * *}$ \\
& $(0.0308)$ & $(0.0345)$ \\
\hline ASVAB score & & $1.136^{* * *}$ \\
\hline ASVAB score squared & & $(0.1754)$ \\
\hline Mean value & & -0.166 \\
\hline Observations & 0.324 & $(0.1601)$ \\
\hline Pseudo $R^{2}$ & 2,781 & 0.324 \\
\hline NOTE: Marginal effects; standard errors are in parentheses. ${ }^{*} p<0.10$, \\
** $p<0.05,{ }^{* * *} p<0.01$. & & 2,781 \\
\hline
\end{tabular}

probability of men obtaining a four-year college degree or higher by 36 percentage points. Once we control for the ability measures (Column 2), a juvenile conviction leads to a 27.2- percentagepoint reduction in the probability of men graduating with a four-year college degree or higher and both race dummies lose statistical significance.

Tables 5 and 6 repeat the analysis for women. After controlling for the ability measures, for women, a juvenile conviction increases the probability of dropping out of high school by 1.4 percentage points (Column 2 of Table 5) and decreases the probability of graduating with a four-year college degree or higher by 34.1 percentage points (Column 2 of Table 6).

Compared with the existing studies, Kirk and Sampson (2013) find a larger effect of an arrest on high school dropout probability, which is likely due to a difference in how dropout is defined: In the Kirk and Sampson study, high school dropouts include individuals who went on to obtain a GED.

\subsection{Juvenile Conviction and Labor Market Employment}

Section 4.1 shows that individuals with a juvenile conviction have worse educational outcomes and hence may have worse labor market outcomes. In this section, we show that a juvenile record has a negative impact on labor market employment even after controlling for education and ability. Employment and attachment to the labor market are important to understanding the amount of human capital workers accumulate and their wage growth over time, all important determinants of the likelihood of recidivism and future incarceration.

We find large and statistically significant negative impacts of a juvenile conviction on both employment (extensive margin) and full-time employment (intensive margin) for men. In contrast, we find that for women, a juvenile conviction does not have a statistically significant impact on 
Table 7

The Effects of a Juvenile Conviction on Adult Male Labor Market Employment

\begin{tabular}{|c|c|c|c|c|c|c|}
\hline & (1) & $(2)$ & (3) & (4) & (5) & (6) \\
\hline Juvenile conviction & $\begin{array}{c}-0.078^{* * *} \\
(0.0120)\end{array}$ & $\begin{array}{c}-0.066^{* * *} \\
(0.0117)\end{array}$ & $\begin{array}{c}-0.035^{* * *} \\
(0.0106)\end{array}$ & $\begin{array}{c}-0.021^{* * *} \\
(0.0075)\end{array}$ & $\begin{array}{c}-0.046^{* * *} \\
(0.0135)\end{array}$ & $\begin{array}{c}-0.030 * * * \\
(0.0100)\end{array}$ \\
\hline Race $=$ Black & $\begin{array}{c}-0.109 * * * \\
(0.0081)\end{array}$ & $\begin{array}{c}-0.070^{* * *} \\
(0.0091)\end{array}$ & $\begin{array}{c}-0.064^{* * *} \\
(0.0086)\end{array}$ & $\begin{array}{c}-0.030^{* * *} \\
(0.0054)\end{array}$ & $\begin{array}{c}-0.082^{* * *} \\
(0.0110)\end{array}$ & $\begin{array}{c}-0.040 * * * \\
(0.0072)\end{array}$ \\
\hline Race $=$ Hispanic & $\begin{array}{l}-0.015 \\
(0.0107)\end{array}$ & $\begin{array}{c}0.009 \\
(0.0114)\end{array}$ & $\begin{array}{c}0.011 \\
(0.0105)\end{array}$ & $\begin{array}{c}0.007 \\
(0.0064)\end{array}$ & $\begin{array}{c}0.015 \\
(0.0136)\end{array}$ & $\begin{array}{c}0.011 \\
(0.0087)\end{array}$ \\
\hline Age & $\begin{array}{c}0.004^{* * *} \\
(0.0007)\end{array}$ & $\begin{array}{l}0.004^{* * *} \\
(0.0008)\end{array}$ & $\begin{array}{c}0.002^{* *} \\
(0.0007)\end{array}$ & $\begin{array}{c}-0.023^{* * *} \\
(0.0013)\end{array}$ & $\begin{array}{c}0.002^{* *} \\
(0.0009)\end{array}$ & $\begin{array}{c}-0.032^{* * *} \\
(0.0018)\end{array}$ \\
\hline ASVAB score & & $\begin{array}{l}0.387^{* * *} \\
(0.0592)\end{array}$ & $\begin{array}{l}0.329 * * * \\
(0.0582)\end{array}$ & $\begin{array}{c}0.094^{* * *} \\
(0.0325)\end{array}$ & $\begin{array}{l}0.422^{* * *} \\
(0.0771)\end{array}$ & $\begin{array}{l}0.115^{* * * *} \\
(0.0441)\end{array}$ \\
\hline ASVAB score squared & & $\begin{array}{c}-0.281^{* * *} \\
(0.0609)\end{array}$ & $\begin{array}{c}-0.316^{* * *} \\
(0.0598)\end{array}$ & $\begin{array}{c}-0.105^{* * *} \\
(0.0340)\end{array}$ & $\begin{array}{c}-0.412^{* * * *} \\
(0.0809)\end{array}$ & $\begin{array}{c}-0.133^{* * *} \\
(0.0468)\end{array}$ \\
\hline GED & & & $\begin{array}{c}0.017 \\
(0.0132)\end{array}$ & $\begin{array}{c}0.061^{* * *} \\
(0.0087)\end{array}$ & $\begin{array}{c}0.022 \\
(0.0166)\end{array}$ & $\begin{array}{c}0.084^{* * *} \\
(0.0116)\end{array}$ \\
\hline High school diploma & & & $\begin{array}{l}0.064^{* * *} \\
(0.0121)\end{array}$ & $\begin{array}{l}0.038^{* * *} \\
(0.0070)\end{array}$ & $\begin{array}{l}0.081^{* * *} \\
(0.0152)\end{array}$ & $\begin{array}{l}0.051^{* * *} \\
(0.0092)\end{array}$ \\
\hline Associate college degree & & & $\begin{array}{c}0.117^{* * *} \\
(0.0252)\end{array}$ & $\begin{array}{c}0.214^{* * *} \\
(0.0205)\end{array}$ & $\begin{array}{c}0.148^{* * *} \\
(0.0316)\end{array}$ & $\begin{array}{c}0.293^{* * *} \\
(0.0272)\end{array}$ \\
\hline $\begin{array}{l}\text { Four-year college degree } \\
\text { or higher }\end{array}$ & & & $\begin{array}{l}0.199 * * * \\
(0.0191)\end{array}$ & $\begin{array}{l}0.297^{* * *} \\
(0.0141)\end{array}$ & & \\
\hline Years worked & & & & $\begin{array}{l}0.049 * * * \\
(0.0023)\end{array}$ & & $\begin{array}{l}0.066^{* * *} \\
(0.0030)\end{array}$ \\
\hline Years worked squared & & & & $\begin{array}{l}-0.001^{* * *} \\
(0.0002)\end{array}$ & & $\begin{array}{l}-0.002^{* * *} \\
(0.0002)\end{array}$ \\
\hline Mean value & 0.846 & 0.846 & 0.846 & 0.852 & 0.824 & 0.829 \\
\hline Observations & 26,610 & 26,610 & 26,610 & 25,757 & 22,407 & 21,596 \\
\hline Pseudo $R^{2}$ & 0.036 & 0.057 & 0.084 & 0.207 & 0.057 & 0.189 \\
\hline
\end{tabular}

NOTE: Marginal effects; standard errors are in parentheses. ${ }^{*} p<0.10,{ }^{* *} p<0.05,{ }^{* * *} p<0.01$.

employment (extensive margin), but it does have a statistically significant negative impact on fulltime employment probability conditional on employment (intensive margin).

Table 7 examines the marginal effects of a juvenile conviction on male labor market employment using a logit regression model. Controlling for age and two race dummies, a juvenile conviction reduces the probability of employment by 7.8 percentage points for men (Column 1 ). Columns 2 , 3 , and 4 sequentially add controls for ASVAB scores, educational attainment, and labor market experience. With the test scores included (Column 2), the magnitudes of the negative effects on men become smaller: A juvenile conviction now reduces the probablity of employment by 6.6 percentage points and also reduces the coefficient on the race dummy for Black workers, but it remains statistically significant. These findings suggest a role for a selection effect of innate skills on the probability of unemployment. Adding educational attainment has a large effect on the probability of employment for men and reduces it further to 3.5 percentage points, which can be due to different traits 


\section{Table 8}

The Effects of a Juvenile Conviction on Adult Male Labor Market Full-Time Employment (Among Employed Workers)

\begin{tabular}{|c|c|c|c|c|c|c|}
\hline & (1) & $(2)$ & (3) & (4) & (5) & (6) \\
\hline Juvenile conviction & $\begin{array}{c}-0.107^{* * *} \\
(0.0211)\end{array}$ & $\begin{array}{c}-0.104 * * * \\
(0.0211)\end{array}$ & $\begin{array}{c}-0.076^{* * *} \\
(0.0217)\end{array}$ & $\begin{array}{c}-0.067^{* * *} \\
(0.0224)\end{array}$ & $\begin{array}{c}-0.080 * * * \\
(0.0233)\end{array}$ & $\begin{array}{c}-0.069^{* * *} \\
(0.0246)\end{array}$ \\
\hline Race $=$ Black & $\begin{array}{c}-0.098^{* * *} \\
(0.0129)\end{array}$ & $\begin{array}{c}-0.086^{* * *} \\
(0.0142)\end{array}$ & $\begin{array}{c}-0.087^{* * *} \\
(0.0142)\end{array}$ & $\begin{array}{c}-0.067^{* * *} \\
(0.0145)\end{array}$ & $\begin{array}{c}-0.093^{* * *} \\
(0.0159)\end{array}$ & $\begin{array}{c}-0.066^{* * *} \\
(0.0163)\end{array}$ \\
\hline Race $=$ Hispanic & $\begin{array}{l}-0.019 \\
(0.0136)\end{array}$ & $\begin{array}{c}-0.011 \\
(0.0143)\end{array}$ & $\begin{array}{l}-0.009 \\
(0.0142)\end{array}$ & $\begin{array}{l}-0.003 \\
(0.0143)\end{array}$ & $\begin{array}{l}-0.007 \\
(0.0159)\end{array}$ & $\begin{array}{c}0.001 \\
(0.0161)\end{array}$ \\
\hline Age & $\begin{array}{l}0.031^{* * *} \\
(0.0011)\end{array}$ & $\begin{array}{l}0.031^{* * *} \\
(0.0011)\end{array}$ & $\begin{array}{l}0.029 * * * \\
(0.0012)\end{array}$ & $\begin{array}{c}-0.010^{* * *} \\
(0.0030)\end{array}$ & $\begin{array}{l}0.029 * * * \\
(0.0013)\end{array}$ & $\begin{array}{c}-0.020^{* * * *} \\
(0.0038)\end{array}$ \\
\hline ASVAB score & & $\begin{array}{c}0.103 \\
(0.0782)\end{array}$ & $\begin{array}{c}0.075 \\
(0.0802)\end{array}$ & $\begin{array}{l}-0.055 \\
(0.0804)\end{array}$ & $\begin{array}{c}0.203^{* *} \\
(0.0940)\end{array}$ & $\begin{array}{c}0.028 \\
(0.0947)\end{array}$ \\
\hline ASVAB score squared & & $\begin{array}{l}-0.062 \\
(0.0761)\end{array}$ & $\begin{array}{l}-0.102 \\
(0.0786)\end{array}$ & $\begin{array}{l}-0.004 \\
(0.0787)\end{array}$ & $\begin{array}{c}-0.268^{* * *} \\
(0.0972)\end{array}$ & $\begin{array}{l}-0.130 \\
(0.0975)\end{array}$ \\
\hline GED & & & $\begin{array}{l}-0.004 \\
(0.0240)\end{array}$ & $\begin{array}{c}0.052^{* *} \\
(0.0246)\end{array}$ & $\begin{array}{l}-0.005 \\
(0.0254)\end{array}$ & $\begin{array}{c}0.068^{* *} \\
(0.0266)\end{array}$ \\
\hline High school diploma & & & $\begin{array}{l}0.056^{* * * *} \\
(0.0208)\end{array}$ & $\begin{array}{c}0.050 * * \\
(0.0208)\end{array}$ & $\begin{array}{l}0.061^{* * *} \\
(0.0220)\end{array}$ & $\begin{array}{c}0.053^{* *} \\
(0.0221)\end{array}$ \\
\hline Associate college degree & & & $\begin{array}{l}0.108^{* * *} \\
(0.0310)\end{array}$ & $\begin{array}{l}0.265^{* * *} \\
(0.0342)\end{array}$ & $\begin{array}{l}0.118^{* * *} \\
(0.0326)\end{array}$ & $\begin{array}{l}0.325^{* * *} \\
(0.0384)\end{array}$ \\
\hline $\begin{array}{l}\text { Four-year college degree } \\
\text { or higher }\end{array}$ & & & $\begin{array}{l}0.137^{* * *} \\
(0.0263)\end{array}$ & $\begin{array}{l}0.349 * * * \\
(0.0316)\end{array}$ & & \\
\hline Years worked & & & & $\begin{array}{l}0.074^{* * *} \\
(0.0044)\end{array}$ & & $\begin{array}{l}0.086^{* * *} \\
(0.0056)\end{array}$ \\
\hline Years worked squared & & & & $\begin{array}{l}-0.002^{* * *} \\
(0.0003)\end{array}$ & & $\begin{array}{l}-0.002^{* * *} \\
(0.0003)\end{array}$ \\
\hline Mean value & 0.652 & 0.652 & 0.652 & 0.655 & 0.624 & 0.626 \\
\hline Observations & 22,487 & 22,487 & 22,487 & 21,908 & 18,424 & 17,883 \\
\hline Pseudo $R^{2}$ & 0.057 & 0.057 & 0.062 & 0.087 & 0.051 & 0.082 \\
\hline
\end{tabular}

NOTE: Marginal effects; standard errors are in parentheses. ${ }^{*} p<0.10,{ }^{* *} p<0.05,{ }^{* * *} p<0.01$.

and unobserved skills of workers who have higher educational attainment and also due to differences in the labor market conditions for high- and low-skilled workers. As seen in Column 4, which is the table's most exhaustive specification and includes labor market experience in the regression, a juvenile conviction reduces the probability of employment for men by 2.1 percentage points. This is not surprising, because workers who are attached to the labor market and have more experience accumulate more human capital and are more likely to continue to be employed. Another interesting finding is that as we move from Column 1 to Column 4, the negative impact associated with the Black race dummy becomes smaller in magnitude, moving from -10.9 percentage points to -3.0 percentage points. Columns 5 and 6 focus on men without a four-year college degree or higher. This subpopulation has low skills and may be more vulnerable to the negative impact of a juvenile conviction. As expected, we find a juvenile conviction has a larger negative impact on employment 
Table 9

The Effects of a Juvenile Conviction on Adult Female Labor Market Employment

\begin{tabular}{|c|c|c|c|c|c|c|}
\hline & (1) & $(2)$ & (3) & (4) & (5) & (6) \\
\hline Juvenile conviction & $\begin{array}{r}-0.068^{* *} \\
(0.0303)\end{array}$ & $\begin{array}{l}-0.037 \\
(0.0301)\end{array}$ & $\begin{array}{c}0.009 \\
(0.0284)\end{array}$ & $\begin{array}{c}0.011 \\
(0.0195)\end{array}$ & $\begin{array}{c}0.009 \\
(0.0358)\end{array}$ & $\begin{array}{c}0.012 \\
(0.0256)\end{array}$ \\
\hline Race $=$ Black & $\begin{array}{c}-0.079^{* * *} \\
(0.0127)\end{array}$ & $\begin{array}{c}0.014 \\
(0.0144)\end{array}$ & $\begin{array}{l}-0.002 \\
(0.0134)\end{array}$ & $\begin{array}{c}0.006 \\
(0.0095)\end{array}$ & $\begin{array}{l}-0.009 \\
(0.0174)\end{array}$ & $\begin{array}{l}-0.001 \\
(0.0127)\end{array}$ \\
\hline Race $=$ Hispanic & $\begin{array}{l}-0.022 \\
(0.0142)\end{array}$ & $\begin{array}{c}0.038^{* *} \\
(0.0151)\end{array}$ & $\begin{array}{c}0.036^{* *} \\
(0.0147)\end{array}$ & $\begin{array}{c}0.025^{* *} \\
(0.0106)\end{array}$ & $\begin{array}{c}0.048^{* *} \\
(0.0190)\end{array}$ & $\begin{array}{c}0.033^{* *} \\
(0.0142)\end{array}$ \\
\hline Age & $\begin{array}{l}-0.001 \\
(0.0010)\end{array}$ & $\begin{array}{c}-0.003^{* * * *} \\
(0.0010)\end{array}$ & $\begin{array}{c}-0.007^{* * *} \\
(0.0010)\end{array}$ & $\begin{array}{c}-0.040^{* * *} \\
(0.0018)\end{array}$ & $\begin{array}{c}-0.007^{* * *} \\
(0.0013)\end{array}$ & $\begin{array}{c}-0.055^{* * *} \\
(0.0026)\end{array}$ \\
\hline ASVAB score & & $\begin{array}{l}0.613^{* * *} \\
(0.0829)\end{array}$ & $\begin{array}{l}0.378^{* * *} \\
(0.0802)\end{array}$ & $\begin{array}{c}0.088 \\
(0.0576)\end{array}$ & $\begin{array}{l}0.513^{* * *} \\
(0.1081)\end{array}$ & $\begin{array}{c}0.094 \\
(0.0801)\end{array}$ \\
\hline ASVAB score squared & & $\begin{array}{c}-0.313^{* * *} \\
(0.0815)\end{array}$ & $\begin{array}{c}-0.272^{* * *} \\
(0.0798)\end{array}$ & $\begin{array}{l}-0.052 \\
(0.0614)\end{array}$ & $\begin{array}{c}-0.404^{* * *} \\
(0.1137)\end{array}$ & $\begin{array}{l}-0.063 \\
(0.0901)\end{array}$ \\
\hline GED & & & $\begin{array}{l}0.107^{* * * *} \\
(0.0226)\end{array}$ & $\begin{array}{c}0.137^{* * *} \\
(0.0169)\end{array}$ & $\begin{array}{c}0.129 * * * \\
(0.0275)\end{array}$ & $\begin{array}{c}0.182^{* * *} \\
(0.0215)\end{array}$ \\
\hline High school diploma & & & $\begin{array}{c}0.163^{* * *} \\
(0.0194)\end{array}$ & $\begin{array}{c}0.100 * * * \\
(0.0130)\end{array}$ & $\begin{array}{c}0.198^{* * *} \\
(0.0235)\end{array}$ & $\begin{array}{c}0.124^{* * *} \\
(0.0162)\end{array}$ \\
\hline Associate college degree & & & $\begin{array}{l}0.223^{* * *} \\
(0.0331)\end{array}$ & $\begin{array}{c}0.338^{* * *} \\
(0.0334)\end{array}$ & $\begin{array}{l}0.272 * * * \\
(0.0404)\end{array}$ & $\begin{array}{l}0.454^{* * *} \\
(0.0455)\end{array}$ \\
\hline $\begin{array}{l}\text { Four-year college degree } \\
\text { or higher }\end{array}$ & & & $\begin{array}{l}0.338^{* * *} \\
(0.0252)\end{array}$ & $\begin{array}{l}0.471^{* * *} \\
(0.0199)\end{array}$ & & \\
\hline Years worked & & & & $\begin{array}{l}0.064^{* * *} \\
(0.0038)\end{array}$ & & $\begin{array}{l}0.094^{* * * *} \\
(0.0055)\end{array}$ \\
\hline Years worked squared & & & & $\begin{array}{l}-0.001^{* * *} \\
(0.0003)\end{array}$ & & $\begin{array}{l}-0.002^{* * *} \\
(0.0004)\end{array}$ \\
\hline Mean value & 0.770 & 0.770 & 0.770 & 0.775 & 0.728 & 0.732 \\
\hline Observations & 26,949 & 26,949 & 26,949 & 26,273 & 20,948 & 20,345 \\
\hline Pseudo $R^{2}$ & 0.006 & 0.049 & 0.085 & 0.178 & 0.053 & 0.166 \\
\hline
\end{tabular}

NOTE: Marginal effects; standard errors are in parentheses. ${ }^{*} p<0.10,{ }^{* *} p<0.05,{ }^{* * *} p<0.01$.

in this population. In the table's most exhaustive specification (Column 6), a juvenile conviction reduces the probability of employment by 3 percentage points for men without a four-year college degree or higher. In all specifications, the Black coefficient remains significant. One possible explanation for this finding is that the type of labor experience Black workers receive is different from that of White workers. We further explore this possibility below; however, this finding is consistent with labor market discrimination in hiring and differences in opportunities available to Black workers, as found in Golan, James, and Sanders (2019).

Table 8 reports the marginal effects of a juvenile conviction on the probability of full-time employment for employed men. Typically, full-time employment is associated with higher accumulation of human capital and stronger attachment to the labor market. While qualitatively the results are similar to the ones in Table 7 , the negative effect of a juvenile conviction is larger and not reduced by test scores, education, or experience to the same extent employment is. As seen in 
Table 10

The Effects of a Juvenile Conviction on Adult Female Labor Market Full-Time Employment (Among Employed Workers)

\begin{tabular}{|c|c|c|c|c|c|c|}
\hline & (1) & $(2)$ & (3) & (4) & (5) & (6) \\
\hline Juvenile conviction & $\begin{array}{c}-0.121^{* * *} \\
(0.0310)\end{array}$ & $\begin{array}{c}-0.103^{* * *} \\
(0.0301)\end{array}$ & $\begin{array}{c}-0.064^{* *} \\
(0.0314)\end{array}$ & $\begin{array}{c}-0.064^{* *} \\
(0.0310)\end{array}$ & $\begin{array}{c}-0.076^{* *} \\
(0.0345)\end{array}$ & $\begin{array}{c}-0.082^{* *} \\
(0.0347)\end{array}$ \\
\hline Race = Black & $\begin{array}{c}-0.073^{* * *} \\
(0.0143)\end{array}$ & $\begin{array}{l}-0.024 \\
(0.0161)\end{array}$ & $\begin{array}{c}-0.033^{* *} \\
(0.0160)\end{array}$ & $\begin{array}{l}-0.021 \\
(0.0158)\end{array}$ & $\begin{array}{c}-0.040 * * \\
(0.0189)\end{array}$ & $\begin{array}{l}-0.027 \\
(0.0186)\end{array}$ \\
\hline Race $=$ Hispanic & $\begin{array}{l}-0.009 \\
(0.0160)\end{array}$ & $\begin{array}{c}0.024 \\
(0.0170)\end{array}$ & $\begin{array}{c}0.031^{*} \\
(0.0174)\end{array}$ & $\begin{array}{r}0.035^{* *} \\
(0.0172)\end{array}$ & $\begin{array}{r}0.043^{* *} \\
(0.0197)\end{array}$ & $\begin{array}{r}0.047^{* *} \\
(0.0196)\end{array}$ \\
\hline Age & $\begin{array}{l}0.032^{* * *} \\
(0.0013)\end{array}$ & $\begin{array}{l}0.031^{* * *} \\
(0.0013)\end{array}$ & $\begin{array}{l}0.026^{* * *} \\
(0.0014)\end{array}$ & $\begin{array}{c}0.000 \\
(0.0029)\end{array}$ & $\begin{array}{l}0.027^{* * *} \\
(0.0016)\end{array}$ & $\begin{array}{c}-0.008^{* *} \\
(0.0037)\end{array}$ \\
\hline ASVAB score & & $\begin{array}{l}0.367^{* * *} \\
(0.0932)\end{array}$ & $\begin{array}{c}0.219 * * \\
(0.0958)\end{array}$ & $\begin{array}{c}0.121 \\
(0.0971)\end{array}$ & $\begin{array}{c}0.292^{* *} \\
(0.1149)\end{array}$ & $\begin{array}{c}0.144 \\
(0.1171)\end{array}$ \\
\hline ASVAB score squared & & $\begin{array}{c}-0.197^{* *} \\
(0.0884)\end{array}$ & $\begin{array}{c}-0.185^{* *} \\
(0.0896)\end{array}$ & $\begin{array}{l}-0.119 \\
(0.0908)\end{array}$ & $\begin{array}{c}-0.272^{* *} \\
(0.1168)\end{array}$ & $\begin{array}{l}-0.156 \\
(0.1185)\end{array}$ \\
\hline GED & & & $\begin{array}{c}0.077^{* *} \\
(0.0338)\end{array}$ & $\begin{array}{l}0.117^{* * *} \\
(0.0341)\end{array}$ & $\begin{array}{c}0.080^{* *} \\
(0.0351)\end{array}$ & $\begin{array}{l}0.132^{* * * *} \\
(0.0361)\end{array}$ \\
\hline High school diploma & & & $\begin{array}{l}0.142^{* * *} \\
(0.0277)\end{array}$ & $\begin{array}{l}0.124^{* * *} \\
(0.0287)\end{array}$ & $\begin{array}{l}0.147^{* * *} \\
(0.0289)\end{array}$ & $\begin{array}{l}0.122^{* * * *} \\
(0.0306)\end{array}$ \\
\hline Associate college degree & & & $\begin{array}{l}0.194^{* * *} \\
(0.0374)\end{array}$ & $\begin{array}{l}0.303^{* * *} \\
(0.0404)\end{array}$ & $\begin{array}{l}0.203^{* * *} \\
(0.0391)\end{array}$ & $\begin{array}{l}0.347^{* * * *} \\
(0.0444)\end{array}$ \\
\hline $\begin{array}{l}\text { Four-year college degree } \\
\text { or higher }\end{array}$ & & & $\begin{array}{l}0.269^{* * *} \\
(0.0314)\end{array}$ & $\begin{array}{l}0.404^{* * *} \\
(0.0345)\end{array}$ & & \\
\hline Years worked & & & & $\begin{array}{l}0.059^{* * *} \\
(0.0050)\end{array}$ & & $\begin{array}{l}0.070^{* * *} \\
(0.0065)\end{array}$ \\
\hline Years worked squared & & & & $\begin{array}{l}-0.002^{* * *} \\
(0.0004)\end{array}$ & & $\begin{array}{l}-0.002^{* * *} \\
(0.0004)\end{array}$ \\
\hline Mean value & 0.576 & 0.576 & 0.576 & 0.577 & 0.520 & 0.521 \\
\hline Observations & 20,729 & 20,729 & 20,729 & 20,341 & 15,221 & 14,885 \\
\hline Pseudo $R^{2}$ & 0.046 & 0.051 & 0.061 & 0.076 & 0.043 & 0.061 \\
\hline
\end{tabular}

NOTE: Marginal effects; standard errors are in parentheses. ${ }^{*} p<0.10,{ }^{* *} p<0.05,{ }^{* * *} p<0.01$.

Column 4 of Table 8 , the table's most exhaustive specification, conditional on ability, education, and labor market experience, having a juvenile conviction reduces the probability of full-time employment for these men by 6.7 percentage points. This estimate is statistically significant at the 1 percent level. Columns 5 and 6 focus on men in this group without a four-year college degree or higher. As seen in Column 6, having a juvenile conviction reduces the probability of full-time employment by 6.9 percentage points for employed men without a four-year college degree or higher.

Tables 9 and 10 present the analogous estimates for women. As seen in Columns 2 to 6, once we control for test scores, there is no statistically significant relationship between a juvenile conviction and employment for these women. This result is robust to excluding women with a four-year college degree or higher from the sample (Columns 5 and 6). Hence, the observed employment gap between women with and without a juvenile conviction shown in Figure 2B is primarily explained by the differences in ability and education between the two groups. 
Our results suggest a large and statistically significant negative impact of a juvenile conviction on the probability of full-time employment for employed woman (Table 10). This result is robust across all specifications and is particularly larger for the less-educated of this group. Under the table's most exhaustive specification (Column 4), a juvenile conviction reduces the probability of full-time employment by 6.4 percentage points for all employed woman and by 8.2 percentage points for employed woman who do not have a four-year college degree or higher (Column 6). This result is significant because workers who do not work full time are less attached to the labor market and are less likely to invest in human capital ex ante and are more likely to commit crimes, as discussed in our conceptual framework. We will discuss recidivism in Section 4.5.

Compared with the literature, our estimated direct effects of a juvenile record on male employment (after controlling for its impact on education) are in line with the estimated long-term effect of an adult crime record on employment from Prescott and Starr (2020). Specifically, Prescott and Starr (2020) estimate that expunging adult criminal records leads to a 6.7-percentage-point increase in the employment rate of all offenders three years later. We do not find a statistically significant impact of a juvenile conviction on female employment. Possible explanations include that (i) a juvenile conviction has a smaller direct impact than an adult crime record on female employment and (ii) the results in Prescott and Starr (2020) are primarily driven by male offenders. Lastly, our results show that a juvenile conviction has large and statistically significant negative effects on fulltime employment both for employed men and employed women.

\subsection{Juvenile Conviction and OTJ Training Investment}

In Sections 4.1 and 4.2 we investigated the effects of a juvenile conviction on education and employment, and our results are broadly in line with the findings of the literature. We found that workers with more past working experience have a higher probability of employment after controlling for juvenile conviction, ability measures, and education. This finding is partly due to workers with more experience acquiring more human capital while working. To further explore the relationship between training experience and juvenile conviction, we investigate the effects of a juvenile conviction on an individual's post-school human capital investment as characterized by occupation-specific employment. To the best of our knowledge, our article is the first to investigate such a relationship. Our findings suggest that a juvenile conviction reduces the probability of working in a high-OTJ-training occupation. As shown in the next section, high-OTJ-training occupations have higher wage levels and faster future wage growth. Hence this channel is an important mechanism through which a juvenile conviction can affect wages.

Table 11 reports the marginal effects of a juvenile conviction on the probability of working in a high-OTJ-training occupation for men. As seen in Column 1, controlling for the race dummies and age, a man with a juvenile conviction is 13.8 percentage points less likely to work in a high-OTJtraining occupation. Once we control for ASVAB scores and education, the direct impact of juvenile conviction on this probability becomes -8.7 percentage points (Column 3 ). In the table's most exhaustive specification (Column 4), a juvenile conviction reduces the probability of working in a high-OTJ-training occupation by 4.9 percentage points for employed men, after controlling for both general work experience and work experience in high-OTJ-training occupations (measured as accumulated years worked in these occupations) as well as education. Notice that both high education levels and experience in high-OTJ-training occupations are correlated with the increased 
Table 11

The Effects of a Juvenile Conviction on Adult Male Occupation Choices: Employed in a High-OTJ-Training Occupation

\begin{tabular}{|c|c|c|c|c|c|c|}
\hline & (1) & $(2)$ & (3) & (4) & (5) & (6) \\
\hline Juvenile conviction & $\begin{array}{c}-0.138^{* * *} \\
(0.0263)\end{array}$ & $\begin{array}{c}-0.126^{* * *} \\
(0.0271)\end{array}$ & $\begin{array}{c}-0.087^{* * *} \\
(0.0272)\end{array}$ & $\begin{array}{c}-0.049^{* *} \\
(0.0201)\end{array}$ & $\begin{array}{c}-0.092 * * * \\
(0.0285)\end{array}$ & $\begin{array}{c}-0.056^{* *} \\
(0.0220)\end{array}$ \\
\hline Race $=$ Black & $\begin{array}{c}-0.188^{* * *} \\
(0.0189)\end{array}$ & $\begin{array}{c}-0.137^{* * *} \\
(0.0206)\end{array}$ & $\begin{array}{c}-0.138^{* * *} \\
(0.0206)\end{array}$ & $\begin{array}{c}-0.069 * * * \\
(0.0156)\end{array}$ & $\begin{array}{c}-0.159 * * * \\
(0.0230)\end{array}$ & $\begin{array}{c}-0.087^{* * *} \\
(0.0181)\end{array}$ \\
\hline Race $=$ Hispanic & $\begin{array}{c}-0.061^{* * *} \\
(0.0196)\end{array}$ & $\begin{array}{l}-0.026 \\
(0.0206)\end{array}$ & $\begin{array}{l}-0.021 \\
(0.0202)\end{array}$ & $\begin{array}{l}-0.007 \\
(0.0144)\end{array}$ & $\begin{array}{l}-0.023 \\
(0.0217)\end{array}$ & $\begin{array}{l}-0.013 \\
(0.0162)\end{array}$ \\
\hline Age & $\begin{array}{l}0.024^{* * *} \\
(0.0014)\end{array}$ & $\begin{array}{l}0.023^{* * *} \\
(0.0014)\end{array}$ & $\begin{array}{l}0.019 * * * \\
(0.0014)\end{array}$ & $\begin{array}{c}0.002 \\
(0.0039)\end{array}$ & $\begin{array}{l}0.020 * * * \\
(0.0016)\end{array}$ & $\begin{array}{c}0.004 \\
(0.0050)\end{array}$ \\
\hline ASVAB score & & $\begin{array}{l}0.511^{* * *} \\
(0.1033)\end{array}$ & $\begin{array}{l}0.483^{* * *} \\
(0.1064)\end{array}$ & $\begin{array}{l}0.373^{* * *} \\
(0.0805)\end{array}$ & $\begin{array}{l}0.466^{* * *} \\
(0.1210)\end{array}$ & $\begin{array}{l}0.378^{* * * *} \\
(0.0933)\end{array}$ \\
\hline ASVAB score squared & & $\begin{array}{c}-0.328^{* * *} \\
(0.1018)\end{array}$ & $\begin{array}{c}-0.423^{* * *} \\
(0.1053)\end{array}$ & $\begin{array}{c}-0.353^{* * *} \\
(0.0797)\end{array}$ & $\begin{array}{c}-0.409 * * * \\
(0.1262)\end{array}$ & $\begin{array}{c}-0.359 * * * \\
(0.0960)\end{array}$ \\
\hline GED & & & $\begin{array}{c}0.018 \\
(0.0341)\end{array}$ & $\begin{array}{c}0.019 \\
(0.0259)\end{array}$ & $\begin{array}{c}0.019 \\
(0.0348)\end{array}$ & $\begin{array}{c}0.021 \\
(0.0280)\end{array}$ \\
\hline High school diploma & & & $\begin{array}{c}0.068^{* *} \\
(0.0293)\end{array}$ & $\begin{array}{l}0.028 \\
(0.0213)\end{array}$ & $\begin{array}{c}0.071^{* *} \\
(0.0300)\end{array}$ & $\begin{array}{c}0.032 \\
(0.0226)\end{array}$ \\
\hline Associate college degree & & & $\begin{array}{l}0.166^{* * *} \\
(0.0470)\end{array}$ & $\begin{array}{c}0.138^{* * *} \\
(0.0388)\end{array}$ & $\begin{array}{l}0.166^{* * *} \\
(0.0479)\end{array}$ & $\begin{array}{c}0.146^{* * *} \\
(0.0441)\end{array}$ \\
\hline $\begin{array}{l}\text { Four-year college degree } \\
\text { or higher }\end{array}$ & & & $\begin{array}{l}0.243^{* * *} \\
(0.0369)\end{array}$ & $\begin{array}{l}0.207^{* * * *} \\
(0.0356)\end{array}$ & & \\
\hline Years worked & & & & $\begin{array}{l}-0.032^{* * *} \\
(0.0074)\end{array}$ & & $\begin{array}{l}-0.017^{*} \\
(0.0085)\end{array}$ \\
\hline Years worked squared & & & & $\begin{array}{l}-0.002^{* * *} \\
(0.0006)\end{array}$ & & $\begin{array}{l}-0.003^{* * *} \\
(0.0006)\end{array}$ \\
\hline $\begin{array}{l}\text { Years worked in high-OTJ- } \\
\text { training occupations }\end{array}$ & & & & $\begin{array}{l}0.149 * * * \\
(0.0045)\end{array}$ & & $\begin{array}{l}0.143^{* * *} \\
(0.0046)\end{array}$ \\
\hline Mean value & 0.521 & 0.521 & 0.521 & 0.549 & 0.477 & 0.501 \\
\hline Observations & 23,912 & 23,912 & 23,912 & 19,114 & 19,859 & 15,292 \\
\hline Pseudo $R^{2}$ & 0.040 & 0.049 & 0.060 & 0.234 & 0.042 & 0.216 \\
\hline
\end{tabular}

NOTE: Marginal effects; standard errors are in parentheses. ${ }^{*} p<0.10,{ }^{* *} p<0.05,{ }^{* * *} p<0.01$.

probability of men working in a high-OTJ-training occupation. Therefore, the 4.9-percentagepoint reduction reported in Column 4 is only the direct contemporaneous effects of a juvenile conviction. The long-term overall effect of a juvenile conviction on OTJ-training occupational choices is larger due to its accumulated effects through education and past work experience. As in our previous tables, Columns 5 and 6 focus on low-skill male workers who do not have a four-year college degree or higher. We find that a juvenile conviction directly reduces the chances of these men working in a high-OTJ-training occupation by 5.6 percentage points. As expected, the negative impact of a juvenile conviction is larger among this disadvantaged population. 
Table 12

The Effects of a Juvenile Conviction on Adult Female Occupation Choices: Employed in a High-OTJ-Training Occupation

\begin{tabular}{|c|c|c|c|c|c|c|}
\hline & (1) & $(2)$ & (3) & (4) & (5) & (6) \\
\hline Juvenile conviction & $\begin{array}{c}-0.165^{* * *} \\
(0.0449)\end{array}$ & $\begin{array}{c}-0.128^{* * *} \\
(0.0470)\end{array}$ & $\begin{array}{c}-0.084^{*} \\
(0.0438)\end{array}$ & $\begin{array}{l}-0.039 \\
(0.0336)\end{array}$ & $\begin{array}{c}-0.108^{* *} \\
(0.0457)\end{array}$ & $\begin{array}{r}-0.074^{* *} \\
(0.0353)\end{array}$ \\
\hline Race $=$ Black & $\begin{array}{c}-0.100 * * * \\
(0.0180)\end{array}$ & $\begin{array}{c}0.006 \\
(0.0192)\end{array}$ & $\begin{array}{c}-0.002 \\
(0.0193)\end{array}$ & $\begin{array}{c}0.004 \\
(0.0165)\end{array}$ & $\begin{array}{l}-0.022 \\
(0.0211)\end{array}$ & $\begin{array}{l}-0.014 \\
(0.0180)\end{array}$ \\
\hline Race $=$ Hispanic & $\begin{array}{l}-0.016 \\
(0.0203)\end{array}$ & $\begin{array}{l}0.059 * * * \\
(0.0215)\end{array}$ & $\begin{array}{l}0.072^{* * *} \\
(0.0219)\end{array}$ & $\begin{array}{c}0.043^{* *} \\
(0.0181)\end{array}$ & $\begin{array}{l}0.067^{* * *} \\
(0.0223)\end{array}$ & $\begin{array}{c}0.041^{* *} \\
(0.0185)\end{array}$ \\
\hline Age & $\begin{array}{l}0.022^{* * *} \\
(0.0015)\end{array}$ & $\begin{array}{l}0.020^{* * *} \\
(0.0015)\end{array}$ & $\begin{array}{l}0.013^{* * *} \\
(0.0016)\end{array}$ & $\begin{array}{c}0.001 \\
(0.0036)\end{array}$ & $\begin{array}{c}0.014^{* * *} \\
(0.0017)\end{array}$ & $\begin{array}{c}0.001 \\
(0.0048)\end{array}$ \\
\hline ASVAB score & & $\begin{array}{l}0.700^{* * *} \\
(0.1124)\end{array}$ & $\begin{array}{l}0.518^{* * *} \\
(0.1152)\end{array}$ & $\begin{array}{c}0.199 * * \\
(0.1003)\end{array}$ & $\begin{array}{l}0.523^{* * *} \\
(0.1241)\end{array}$ & $\begin{array}{c}0.222^{* *} \\
(0.1095)\end{array}$ \\
\hline ASVAB score squared & & $\begin{array}{c}-0.315^{* * *} \\
(0.1062)\end{array}$ & $\begin{array}{c}-0.317^{* * *} \\
(0.1079)\end{array}$ & $\begin{array}{l}-0.115 \\
(0.0929)\end{array}$ & $\begin{array}{c}-0.351^{* * *} \\
(0.1251)\end{array}$ & $\begin{array}{l}-0.153 \\
(0.1094)\end{array}$ \\
\hline GED & & & $\begin{array}{l}0.139 * * * \\
(0.0425)\end{array}$ & $\begin{array}{l}0.133^{* * *} \\
(0.0412)\end{array}$ & $\begin{array}{l}0.126^{* * *} \\
(0.0394)\end{array}$ & $\begin{array}{c}0.128^{* * *} \\
(0.0387)\end{array}$ \\
\hline High school diploma & & & $\begin{array}{c}0.172^{* * *} \\
(0.0353)\end{array}$ & $\begin{array}{l}0.133^{* * *} \\
(0.0347)\end{array}$ & $\begin{array}{l}0.157^{* * *} \\
(0.0328)\end{array}$ & $\begin{array}{c}0.115^{* * *} \\
(0.0317)\end{array}$ \\
\hline Associate college degree & & & $\begin{array}{l}0.289 * * * \\
(0.0458)\end{array}$ & $\begin{array}{l}0.262^{* * *} \\
(0.0467)\end{array}$ & $\begin{array}{l}0.261^{* * *} \\
(0.0428)\end{array}$ & $\begin{array}{l}0.254^{* * *} \\
(0.0474)\end{array}$ \\
\hline $\begin{array}{l}\text { Four-year college degree } \\
\text { or higher }\end{array}$ & & & $\begin{array}{l}0.368^{* * *} \\
(0.0393)\end{array}$ & $\begin{array}{l}0.316^{* * *} \\
(0.0431)\end{array}$ & & \\
\hline Years worked & & & & $\begin{array}{l}-0.058^{* * *} \\
(0.0077)\end{array}$ & & $\begin{array}{r}-0.020^{* *} \\
(0.0084)\end{array}$ \\
\hline Years worked squared & & & & $\begin{array}{c}0.000 \\
(0.0007)\end{array}$ & & $\begin{array}{l}-0.001^{*} \\
(0.0007)\end{array}$ \\
\hline $\begin{array}{l}\text { Years worked in high-OTJ- } \\
\text { training occupations }\end{array}$ & & & & $\begin{array}{l}0.162^{* * *} \\
(0.0055)\end{array}$ & & $\begin{array}{l}0.129 * * * \\
(0.0053)\end{array}$ \\
\hline Mean value & 0.413 & 0.413 & 0.413 & 0.445 & 0.343 & 0.367 \\
\hline Observations & 22,762 & 22,762 & 22,762 & 17,424 & 17,149 & 12,239 \\
\hline Pseudo $R^{2}$ & 0.028 & 0.054 & 0.073 & 0.224 & 0.042 & 0.185 \\
\hline
\end{tabular}

NOTE: Marginal effects; standard errors are in parentheses. ${ }^{*} p<0.10,{ }^{* *} p<0.05,{ }^{* * *} p<0.01$.

As with employment, the probability of Black male workers being employed in a high-OTCtraining occupation is substantially lower than that of White male workers, close to 19 percentage points (see Column 1 of Table 11). For Hispanic male workers it is 6.1 percentage points less than that of White male workers. Controlling for test scores reduces the coefficient on the Black indicator variable to 13.7 percentage points (Column 2), and it is not further reduced once education is included (see Column 3). However, experience in high-OTC-training occupations reduces the coefficient on the Black indicator variable to 8.7 percentage points (see Column 6). For Hispanic male workers, the race effect on the probability of employment in a high-OTC-training occupation becomes small and statistically insignificant once we account for ASVAB scores. The fact that Black 
individuals are less likely to be employed in high-OTJ-training occupations is consistent with Golan, James, and Sanders (2019), who find evidence for discrimination in the assignment and promotion of Black workers to occupations with demand for complex and non-routine tasks in the NLSY79. It is likely that these occupations are also occupations with higher training requirements, although this variable is not directly analyzed in their article.

We conduct the same analysis for women in Table 12. Looking at Column 1 of Table 12, women with a juvenile conviction are 16.5 percentage points less likely to be employed in a high-OTCtraining occupation than women without a juvenile conviction. After further controlling for test scores and education, the reduction in the probability of women with a juvenile conviction being employed in a high-OTC-training occupation is 8.4 percentage points (and significant at the 10 percent level; Column 3). Controlling for general work experience and experience in high-OTCtraining occupations, the coefficient in front of the juvenile conviction variable becomes smaller in magnitude ( -3.9 percentage points) and loses statistical significance (Column 4). However, a juvenile conviction may still affect a women's occupational choices through its indirect impact via education. Furthermore, the selection of women into high-OTC-training occupations may be different from that of men due to the effects of fertility and marriage on occupational choices and the glass ceiling women face. 2 These issues, however, are beyond the scope of this article. It is interesting to note that, once we control for test scores, the coefficient on the Black indicator variable becomes small and statistically insignificant, while the coefficient on the Hispanic indicator variable becomes positive and statistically significant.

In Columns 5 and 6 of Table 12, we focus on women without a four-year college degree or higher, who are relatively disadvantaged in the labor market. As seen in Column 6, a juvenile conviction reduces their probability of working in a high-OTJ-training occupation by 7.4 percentage points. Moreover, we find large state dependence in occupational choices, as work experience in high-OTJ-training occupations increases the probability of working in such an occupation in the future. This finding implies that the overall life-cycle effect of a juvenile conviction on an individual's occupational choices is likely to be bigger and more persistent.

\subsection{Juvenile Conviction and Wages}

So far, our results establish that a juvenile conviction reduces a youth's educational achievement, employment, and probability of working in a high-OTJ-training occupation. In this section, we document that the work experience in high-OTJ-training occupations is associated with higher wages and wage growth. Higher wages and income imply a higher opportunity cost of devoting time to crime and a higher opportunity cost of time spent in jail. The observed wage gap by juvenile conviction status (see Figure 3 ) is primarily due to the accumulated effects of a juvenile conviction on employment and occupational choices over time.

We first examine the effect of a juvenile conviction on wage levels. Table 13 presents regression analysis of log hourly wages for employed men. Starting with the estimate in Column 1, we find a statistically significant negative impact of a juvenile conviction on employed men's wages. Columns 2 and 3 repeat the initial estimate, now adding main effects for ability and education sequentially; the negative effects remain statistically significant but smaller in magnitude. Column 4 includes years worked and years worked squared; the coefficient in front of the juvenile conviction variable becomes slightly smaller in magnitude but remains negative and statistically significant. However, 


\section{Table 13}

\section{The Effects of a Juvenile Conviction on Adult Male Log Hourly Wages}

\begin{tabular}{|c|c|c|c|c|c|c|c|c|}
\hline & (1) & $(2)$ & (3) & (4) & (5) & (6) & (7) & (8) \\
\hline Juvenile conviction & $\begin{array}{c}-0.147^{* * *} \\
(0.0295)\end{array}$ & $\begin{array}{c}-0.128^{* * *} \\
(0.0289)\end{array}$ & $\begin{array}{c}-0.077^{* * *} \\
(0.0287)\end{array}$ & $\begin{array}{r}-0.068^{* *} \\
(0.0299)\end{array}$ & $\begin{array}{l}-0.027 \\
(0.0285)\end{array}$ & $\begin{array}{c}-0.087^{* * *} \\
(0.0286)\end{array}$ & $\begin{array}{c}-0.076^{* *} \\
(0.0301)\end{array}$ & $\begin{array}{l}-0.038 \\
(0.0285)\end{array}$ \\
\hline Race $=$ Black & $\begin{array}{c}-0.215^{* * *} \\
(0.0201)\end{array}$ & $\begin{array}{c}-0.147^{* * *} \\
(0.0212)\end{array}$ & $\begin{array}{c}-0.147^{* * *} \\
(0.0206)\end{array}$ & $\begin{array}{c}-0.129 * * * \\
(0.0195)\end{array}$ & $\begin{array}{c}-0.098^{* * *} \\
(0.0211)\end{array}$ & $\begin{array}{c}-0.161^{* * *} \\
(0.0220)\end{array}$ & $\begin{array}{c}-0.135^{* * *} \\
(0.0207)\end{array}$ & $\begin{array}{c}-0.105^{* * *} \\
(0.0224)\end{array}$ \\
\hline Race $=$ Hispanic & $\begin{array}{c}-0.075^{* * *} \\
(0.0196)\end{array}$ & $\begin{array}{l}-0.027 \\
(0.0203)\end{array}$ & $\begin{array}{l}-0.018 \\
(0.0192)\end{array}$ & $\begin{array}{l}-0.020 \\
(0.0187)\end{array}$ & $\begin{array}{l}-0.022 \\
(0.0192)\end{array}$ & $\begin{array}{l}-0.023 \\
(0.0201)\end{array}$ & $\begin{array}{l}-0.024 \\
(0.0195)\end{array}$ & $\begin{array}{l}-0.023 \\
(0.0198)\end{array}$ \\
\hline Age & $\begin{array}{l}0.047^{* * *} \\
(0.0013)\end{array}$ & $\begin{array}{l}0.045^{* * *} \\
(0.0013)\end{array}$ & $\begin{array}{l}0.038^{* * *} \\
(0.0013)\end{array}$ & $\begin{array}{c}0.007^{*} \\
(0.0041)\end{array}$ & $\begin{array}{l}0.016 * * * \\
(0.0049)\end{array}$ & $\begin{array}{l}0.036^{* * *} \\
(0.0014)\end{array}$ & $\begin{array}{l}-0.006 \\
(0.0047)\end{array}$ & $\begin{array}{c}-0.005 \\
(0.0057)\end{array}$ \\
\hline ASVAB score & & $\begin{array}{l}0.320^{* * *} \\
(0.1062)\end{array}$ & $\begin{array}{c}0.298^{* * *} \\
(0.1041)\end{array}$ & $\begin{array}{c}0.197^{*} \\
(0.1043)\end{array}$ & $\begin{array}{c}0.042 \\
(0.1088)\end{array}$ & $\begin{array}{l}0.468^{* * *} \\
(0.1161)\end{array}$ & $\begin{array}{l}0.325^{* * *} \\
(0.1165)\end{array}$ & $\begin{array}{c}0.202^{*} \\
(0.1220)\end{array}$ \\
\hline ASVAB score squared & & $\begin{array}{l}-0.048 \\
(0.1103)\end{array}$ & $\begin{array}{c}-0.207^{*} \\
(0.1068)\end{array}$ & $\begin{array}{l}-0.131 \\
(0.1066)\end{array}$ & $\begin{array}{l}-0.000 \\
(0.1104)\end{array}$ & $\begin{array}{c}-0.433^{* * *} \\
(0.1284)\end{array}$ & $\begin{array}{c}-0.316^{* *} \\
(0.1278)\end{array}$ & $\begin{array}{c}-0.233^{*} \\
(0.1332)\end{array}$ \\
\hline GED & & & $\begin{array}{c}0.012 \\
(0.0303)\end{array}$ & $\begin{array}{c}0.051^{*} \\
(0.0311)\end{array}$ & $\begin{array}{c}0.032 \\
(0.0353)\end{array}$ & $\begin{array}{c}0.011 \\
(0.0303)\end{array}$ & $\begin{array}{c}0.067^{* *} \\
(0.0313)\end{array}$ & $\begin{array}{c}0.062^{*} \\
(0.0352)\end{array}$ \\
\hline High school diploma & & & $\begin{array}{c}0.063^{* *} \\
(0.0260)\end{array}$ & $\begin{array}{c}0.056^{* *} \\
(0.0260)\end{array}$ & $\begin{array}{c}0.043 \\
(0.0295)\end{array}$ & $\begin{array}{c}0.064^{* *} \\
(0.0260)\end{array}$ & $\begin{array}{c}0.055^{* *} \\
(0.0258)\end{array}$ & $\begin{array}{c}0.048^{*} \\
(0.0287)\end{array}$ \\
\hline Associate college degree & & & $\begin{array}{l}0.216^{* * *} \\
(0.0451)\end{array}$ & $\begin{array}{l}0.338^{* * *} \\
(0.0482)\end{array}$ & $\begin{array}{l}0.235^{* * *} \\
(0.0491)\end{array}$ & $\begin{array}{l}0.222^{* * *} \\
(0.0451)\end{array}$ & $\begin{array}{l}0.387^{* * *} \\
(0.0494)\end{array}$ & $\begin{array}{l}0.328^{* * *} \\
(0.0510)\end{array}$ \\
\hline $\begin{array}{l}\text { Four-year college degree } \\
\text { or higher }\end{array}$ & & & $\begin{array}{l}0.328^{* * * *} \\
(0.0345)\end{array}$ & $\begin{array}{l}0.494^{* * *} \\
(0.0408)\end{array}$ & $\begin{array}{l}0.365^{* * *} \\
(0.0475)\end{array}$ & & & \\
\hline Years worked & & & & $\begin{array}{l}0.055^{* * *} \\
(0.0056)\end{array}$ & $\begin{array}{l}0.032^{* * *} \\
(0.0066)\end{array}$ & & $\begin{array}{l}0.066^{* * *} \\
(0.0062)\end{array}$ & $\begin{array}{l}0.053^{* * *} \\
(0.0072)\end{array}$ \\
\hline Years worked squared & & & & $\begin{array}{l}-0.002^{* * *} \\
(0.0003)\end{array}$ & $\begin{array}{l}-0.002^{* * *} \\
(0.0003)\end{array}$ & & $\begin{array}{l}-0.001^{* * *} \\
(0.0003)\end{array}$ & $\begin{array}{l}-0.002^{* * *} \\
(0.0004)\end{array}$ \\
\hline $\begin{array}{l}\text { Years worked in high- } \\
\text { OTJ-training occupations }\end{array}$ & & & & & $\begin{array}{l}0.026 * * * \\
(0.0037)\end{array}$ & & & $\begin{array}{l}0.025^{* * *} \\
(0.0039)\end{array}$ \\
\hline $\begin{array}{l}\text { Employed at high-OTJ } \\
\text { occupation }\end{array}$ & & & & & $\begin{array}{l}0.177^{* * *} \\
(0.0135)\end{array}$ & & & $\begin{array}{l}0.179 * * * \\
(0.0137)\end{array}$ \\
\hline Constant & $\begin{array}{l}1.276^{* * *} \\
(0.0327)\end{array}$ & $\begin{array}{l}1.168^{* * *} \\
(0.0398)\end{array}$ & $\begin{array}{l}1.283^{* * *} \\
(0.0444)\end{array}$ & $\begin{array}{l}1.845^{* * *} \\
(0.0873)\end{array}$ & $\begin{array}{l}1.647^{* * *} \\
(0.0985)\end{array}$ & $\begin{array}{l}1.330^{* * *} \\
(0.0459)\end{array}$ & $\begin{array}{l}2.104^{* * *} \\
(0.0971)\end{array}$ & $\begin{array}{l}2.035^{* * *} \\
(0.1128)\end{array}$ \\
\hline Mean value & 2.384 & 2.384 & 2.384 & 2.385 & 2.404 & 2.310 & 2.310 & 2.324 \\
\hline Observations & 22,009 & 22,009 & 22,009 & 21,456 & 17,770 & 18,097 & 17,579 & 14,147 \\
\hline$R^{2}$ & 0.143 & 0.163 & 0.197 & 0.218 & 0.278 & 0.126 & 0.157 & 0.233 \\
\hline
\end{tabular}

NOTE: Marginal effects; standard errors are in parentheses. ${ }^{*} p<0.10,{ }^{* *} p<0.05,{ }^{* * *} p<0.01$.

as we further add controls for experience in high-OTJ-training occupations and current employment status in those occupations, the direct effect of a juvenile conviction on wages is no longer significant (Column 5). This evidence suggests that the wage effects of a juvenile conviction mainly come from indirect effects through accumulated work experience in high-OTJ-training occupations and current employment status in a high-OTJ-training occupation. However, it can also reflect selection based on unobserved characteristics and traits of the individuals (in the data). In other words, it could be that unobserved skills and traits make individuals more likely to accumulate 


\section{Table 14}

\section{The Effects of a Juvenile Conviction on Adult Female Log Hourly Wages}

\begin{tabular}{|c|c|c|c|c|c|c|c|c|}
\hline & (1) & $(2)$ & (3) & (4) & (5) & (6) & (7) & (8) \\
\hline Juvenile conviction & $\begin{array}{c}-0.211^{* * *} \\
(0.0577)\end{array}$ & $\begin{array}{c}-0.148^{* * *} \\
(0.0531)\end{array}$ & $\begin{array}{l}-0.075 \\
(0.0488)\end{array}$ & $\begin{array}{c}-0.071 \\
(0.0496)\end{array}$ & $\begin{array}{l}-0.045 \\
(0.0551)\end{array}$ & $\begin{array}{c}-0.104^{* *} \\
(0.0510)\end{array}$ & $\begin{array}{c}-0.105^{* *} \\
(0.0519)\end{array}$ & $\begin{array}{l}-0.079 \\
(0.0590)\end{array}$ \\
\hline Race $=$ Black & $\begin{array}{c}-0.134^{* * *} \\
(0.0199)\end{array}$ & $\begin{array}{c}0.019 \\
(0.0196)\end{array}$ & $\begin{array}{c}0.009 \\
(0.0184)\end{array}$ & $\begin{array}{c}0.024 \\
(0.0183)\end{array}$ & $\begin{array}{c}0.022 \\
(0.0202)\end{array}$ & $\begin{array}{c}0.009 \\
(0.0203)\end{array}$ & $\begin{array}{c}0.028 \\
(0.0200)\end{array}$ & $\begin{array}{c}0.025 \\
(0.0220)\end{array}$ \\
\hline Race $=$ Hispanic & $\begin{array}{c}-0.045^{* *} \\
(0.0201)\end{array}$ & $\begin{array}{l}0.064^{* * *} \\
(0.0207)\end{array}$ & $\begin{array}{l}0.092^{* * * *} \\
(0.0196)\end{array}$ & $\begin{array}{l}0.098 * * * \\
(0.0196)\end{array}$ & $\begin{array}{l}0.065^{* * *} \\
(0.0211)\end{array}$ & $\begin{array}{l}0.107^{* * *} \\
(0.0219)\end{array}$ & $\begin{array}{l}0.111^{* * *} \\
(0.0217)\end{array}$ & $\begin{array}{c}0.083^{* * *} \\
(0.0237)\end{array}$ \\
\hline Age & $\begin{array}{l}0.049 * * * \\
(0.0016)\end{array}$ & $\begin{array}{l}0.044^{* * *} \\
(0.0015)\end{array}$ & $\begin{array}{l}0.031^{* * * *} \\
(0.0016)\end{array}$ & $\begin{array}{c}0.009 * * \\
(0.0039)\end{array}$ & $\begin{array}{l}0.025^{* * *} \\
(0.0047)\end{array}$ & $\begin{array}{l}0.027^{* * *} \\
(0.0017)\end{array}$ & $\begin{array}{c}-0.005 \\
(0.0050)\end{array}$ & $\begin{array}{c}0.010 \\
(0.0067)\end{array}$ \\
\hline ASVAB score & & $\begin{array}{l}0.690 * * * \\
(0.1185)\end{array}$ & $\begin{array}{l}0.433^{* * *} \\
(0.1153)\end{array}$ & $\begin{array}{l}0.334^{* * *} \\
(0.1157)\end{array}$ & $\begin{array}{c}0.201 \\
(0.1297)\end{array}$ & $\begin{array}{l}0.503^{* * *} \\
(0.1374)\end{array}$ & $\begin{array}{l}0.366^{* * *} \\
(0.1361)\end{array}$ & $\begin{array}{c}0.261 \\
(0.1600)\end{array}$ \\
\hline ASVAB score squared & & $\begin{array}{l}-0.109 \\
(0.1224)\end{array}$ & $\begin{array}{c}-0.193^{*} \\
(0.1168)\end{array}$ & $\begin{array}{l}-0.128 \\
(0.1172)\end{array}$ & $\begin{array}{l}-0.054 \\
(0.1294)\end{array}$ & $\begin{array}{c}-0.287^{*} \\
(0.1522)\end{array}$ & $\begin{array}{l}-0.190 \\
(0.1496)\end{array}$ & $\begin{array}{c}-0.152 \\
(0.1743)\end{array}$ \\
\hline GED & & & $\begin{array}{l}0.134^{* * *} \\
(0.0422)\end{array}$ & $\begin{array}{c}0.167^{* * *} \\
(0.0426)\end{array}$ & $\begin{array}{c}0.081^{*} \\
(0.0491)\end{array}$ & $\begin{array}{l}0.140^{* * *} \\
(0.0422)\end{array}$ & $\begin{array}{l}0.185^{* * *} \\
(0.0430)\end{array}$ & $\begin{array}{c}0.114^{* *} \\
(0.0510)\end{array}$ \\
\hline High school diploma & & & $\begin{array}{l}0.177^{* * *} \\
(0.0315)\end{array}$ & $\begin{array}{l}0.161^{* * *} \\
(0.0316)\end{array}$ & $\begin{array}{l}0.105^{* * *} \\
(0.0374)\end{array}$ & $\begin{array}{l}0.178^{* * *} \\
(0.0315)\end{array}$ & $\begin{array}{l}0.152^{* * *} \\
(0.0319)\end{array}$ & $\begin{array}{l}0.112^{* * *} \\
(0.0380)\end{array}$ \\
\hline Associate college degree & & & $\begin{array}{l}0.365^{* * *} \\
(0.0477)\end{array}$ & $\begin{array}{l}0.456^{* * *} \\
(0.0510)\end{array}$ & $\begin{array}{l}0.293^{* * *} \\
(0.0593)\end{array}$ & $\begin{array}{l}0.378^{* * *} \\
(0.0478)\end{array}$ & $\begin{array}{l}0.507^{* * *} \\
(0.0532)\end{array}$ & $\begin{array}{l}0.375^{* * *} \\
(0.0655)\end{array}$ \\
\hline $\begin{array}{l}\text { Four-year college degree } \\
\text { or higher }\end{array}$ & & & $\begin{array}{l}0.568 * * * \\
(0.0372)\end{array}$ & $\begin{array}{l}0.680^{* * *} \\
(0.0408)\end{array}$ & $\begin{array}{l}0.476^{* * *} \\
(0.0504)\end{array}$ & & & \\
\hline Years worked & & & & $\begin{array}{l}0.041^{* * *} \\
(0.0055)\end{array}$ & $\begin{array}{l}0.019 * * * \\
(0.0065)\end{array}$ & & $\begin{array}{l}0.045^{* * *} \\
(0.0072)\end{array}$ & $\begin{array}{l}0.024^{* * *} \\
(0.0089)\end{array}$ \\
\hline Years worked squared & & & & $\begin{array}{l}-0.001^{* * *} \\
(0.0004)\end{array}$ & $\begin{array}{l}-0.002^{* * *} \\
(0.0004)\end{array}$ & & $\begin{array}{l}-0.000 \\
(0.0004)\end{array}$ & $\begin{array}{l}-0.001 \\
(0.0005)\end{array}$ \\
\hline $\begin{array}{l}\text { Years worked in high- } \\
\text { OTJ-training occupations }\end{array}$ & & & & & $\begin{array}{l}0.018^{* * *} \\
(0.0045)\end{array}$ & & & $\begin{array}{l}0.018^{* * *} \\
(0.0052)\end{array}$ \\
\hline $\begin{array}{l}\text { Employed at high-OTJ } \\
\text { occupation }\end{array}$ & & & & & $\begin{array}{l}0.182^{* * *} \\
(0.0140)\end{array}$ & & & $\begin{array}{l}0.170^{* * *} \\
(0.0161)\end{array}$ \\
\hline Constant & $\begin{array}{l}1.046^{* * *} \\
(0.0377)\end{array}$ & $\begin{array}{l}0.818^{* * *} \\
(0.0454)\end{array}$ & $\begin{array}{l}1.011^{* * *} \\
(0.0493)\end{array}$ & $\begin{array}{l}1.438 * * * \\
(0.0869) \\
\end{array}$ & $\begin{array}{l}1.164 * * * \\
(0.0992)\end{array}$ & $\begin{array}{l}1.097^{* * *} \\
(0.0527)\end{array}$ & $\begin{array}{l}1.742^{* * *} \\
(0.1073)\end{array}$ & $\begin{array}{l}1.474^{* * * *} \\
(0.1362) \\
\end{array}$ \\
\hline Mean value & 2.256 & 2.256 & 2.256 & 2.257 & 2.289 & 2.118 & 2.118 & 2.133 \\
\hline Observations & 20,343 & 20,343 & 20,343 & 19,979 & 15,796 & 14,960 & 14,640 & 10,898 \\
\hline$R^{2}$ & 0.131 & 0.201 & 0.278 & 0.288 & 0.332 & 0.124 & 0.144 & 0.191 \\
\hline
\end{tabular}

NOTE: Marginal effects; standard errors are in parentheses. ${ }^{*} p<0.10,{ }^{* *} p<0.05,{ }^{* * *} p<0.01$.

experience and human capital and as a result these individuals earn higher wages. This can be seen from the statistically positive coefficients in front of both experience in high-OTJ-training occupations and current employment in a high-OTJ-training occupation. Our findings are similar when we focus on less-skilled men who do not have a four-year college degree or higher (Columns 6 to 8).

Table 14 repeats the analysis for employed women. The estimates in Columns 1 and 2 suggest that a juvenile conviction has a negative impact on their wages. However, as we introduce dummies for the education categories, the coefficient of a juvenile conviction loses statistical significance. 
Table 15

The Effects of a Juvenile Conviction on Adult Male 10-Year Percent Changes of Hourly Wages

\begin{tabular}{|c|c|c|c|c|c|c|}
\hline & (1) & $(2)$ & (3) & (4) & (5) & (6) \\
\hline Juvenile conviction & $\begin{array}{l}-40.730^{* * *} \\
(10.282)\end{array}$ & $\begin{array}{l}-37.674^{* * *} \\
(10.109)\end{array}$ & $\begin{array}{l}-34.127^{* * *} \\
(10.548)\end{array}$ & $\begin{array}{c}-25.814^{* * *} \\
(9.739)\end{array}$ & $\begin{array}{l}-34.445^{* * *} \\
(10.636)\end{array}$ & $\begin{array}{c}-26.056^{* * *} \\
(9.797)\end{array}$ \\
\hline Race $=$ Black & $\begin{array}{c}-24.034^{* *} \\
(9.744)\end{array}$ & $\begin{array}{c}-9.385 \\
(9.996)\end{array}$ & $\begin{array}{c}-9.239 \\
(10.159)\end{array}$ & $\begin{array}{c}-1.803 \\
(10.513)\end{array}$ & $\begin{array}{c}-14.393 \\
(10.062)\end{array}$ & $\begin{array}{c}-5.950 \\
(10.366)\end{array}$ \\
\hline Race $=$ Hispanic & $\begin{array}{r}-15.135^{*} \\
(8.808)\end{array}$ & $\begin{array}{l}-4.010 \\
(8.795)\end{array}$ & $\begin{array}{c}-3.841 \\
(8.840)\end{array}$ & $\begin{array}{c}3.996 \\
(9.118)\end{array}$ & $\begin{array}{l}-7.347 \\
(8.446)\end{array}$ & $\begin{array}{c}1.019 \\
(8.535)\end{array}$ \\
\hline Age & $\begin{array}{c}-4.650 \\
(2.853)\end{array}$ & $\begin{array}{c}-5.751^{* *} \\
(2.871)\end{array}$ & $\begin{array}{l}-7.541^{* *} \\
(3.559)\end{array}$ & $\begin{array}{c}-11.230^{* * * *} \\
(4.163)\end{array}$ & $\begin{array}{c}-7.507^{* *} \\
(3.570)\end{array}$ & $\begin{array}{c}-11.375^{* * * *} \\
(4.186)\end{array}$ \\
\hline ASVAB score & & $\begin{array}{l}147.023^{* * *} \\
(53.283)\end{array}$ & $\begin{array}{l}145.579^{* * * *} \\
(55.591)\end{array}$ & $\begin{array}{l}108.913^{* *} \\
(54.104)\end{array}$ & $\begin{array}{c}118.132^{* *} \\
(58.625)\end{array}$ & $\begin{array}{c}82.551 \\
(56.990)\end{array}$ \\
\hline ASVAB score squared & & $\begin{array}{l}-84.646 \\
(55.010)\end{array}$ & $\begin{array}{c}-89.760 \\
(56.049)\end{array}$ & $\begin{array}{c}-64.766 \\
(55.505)\end{array}$ & $\begin{array}{c}-59.674 \\
(61.199)\end{array}$ & $\begin{array}{c}-36.798 \\
(60.867)\end{array}$ \\
\hline GED & & & $\begin{array}{c}-13.364 \\
(22.696)\end{array}$ & $\begin{array}{c}-17.409 \\
(26.311)\end{array}$ & $\begin{array}{c}-12.520 \\
(22.601)\end{array}$ & $\begin{array}{c}-16.249 \\
(26.206)\end{array}$ \\
\hline High school diploma & & & $\begin{array}{c}4.140 \\
(20.847)\end{array}$ & $\begin{array}{c}-7.065 \\
(23.769)\end{array}$ & $\begin{array}{c}4.631 \\
(20.789)\end{array}$ & $\begin{array}{c}-6.539 \\
(23.718)\end{array}$ \\
\hline Associate college degree & & & $\begin{array}{c}23.102 \\
(32.977)\end{array}$ & $\begin{array}{c}27.678 \\
(36.484)\end{array}$ & $\begin{array}{c}23.050 \\
(32.928)\end{array}$ & $\begin{array}{c}28.152 \\
(36.407)\end{array}$ \\
\hline $\begin{array}{l}\text { Four-year college degree } \\
\text { or higher }\end{array}$ & & & $\begin{array}{l}21.057 \\
(32.260)\end{array}$ & $\begin{array}{c}30.340 \\
(36.103)\end{array}$ & & \\
\hline $\begin{array}{l}\text { Years worked in high-OTJ- } \\
\text { training occupations }\end{array}$ & & & & $\begin{array}{l}3.509 * * * \\
(1.260)\end{array}$ & & $\begin{array}{l}3.741^{* * *} \\
(1.277)\end{array}$ \\
\hline Constant & $\begin{array}{l}232.643^{* * * *} \\
(84.279) \\
\end{array}$ & $\begin{array}{l}218.839^{* * *} \\
(83.752) \\
\end{array}$ & $\begin{array}{l}269.608^{* * *} \\
(103.512)\end{array}$ & $\begin{array}{l}367.359 * * * \\
(119.797)\end{array}$ & $\begin{array}{l}273.385^{* * *} \\
(103.867)\end{array}$ & $\begin{array}{l}374.795^{* * *} \\
(120.575) \\
\end{array}$ \\
\hline Mean value & 86.017 & 86.017 & 86.017 & 83.420 & 84.965 & 82.010 \\
\hline Observations & 952 & 952 & 952 & 792 & 907 & 751 \\
\hline$R^{2}$ & 0.014 & 0.035 & 0.038 & 0.054 & 0.040 & 0.056 \\
\hline
\end{tabular}

NOTE: Marginal effects; standard errors are in parentheses. ${ }^{*} p<0.10,{ }^{* *} p<0.05,{ }^{* * *} p<0.01$.

This finding suggests that many of the negative effects of a juvenile conviction found earlier can be explained by the effects of a juvenile conviction on educational outcomes. The coefficient of the juvenile conviction variable changes little after further controlling for general work experience (Column 4). In Column 5, the estimates suggest that both experience in high-OTJ-training occupations and current employment status in a high-OTJ-training occupation increase wages, which are important mechanisms through which a juvenile conviction can affect wages. A juvenile conviction has a negative wage impact for women without a four-year college degree or higher, but the significance disappears once we control for experience in high-OTJ-training occupations and current employment status in a high-OTJ-training occupation.

An interesting contrast between the hourly wages of men and women is the role of race. Black men earn statistically significant lower wages than White men in all specifications, and Hispanic men generally do not earn significantly different wages from White men. On the other hand, Black 


\section{Table 16}

The Effects of a Juvenile Conviction on Adult Female 10-Year Percent Changes of Hourly Wages

\begin{tabular}{|c|c|c|c|c|c|c|}
\hline & (1) & $(2)$ & (3) & (4) & (5) & (6) \\
\hline Juvenile conviction & $\begin{array}{l}-63.858^{* * *} \\
(18.998)\end{array}$ & $\begin{array}{l}-60.016^{* * *} \\
(17.093)\end{array}$ & $\begin{array}{l}-63.292^{* * *} \\
(23.935)\end{array}$ & $\begin{array}{l}-66.399 * * \\
(29.042)\end{array}$ & $\begin{array}{l}-62.997^{* * *} \\
(24.199)\end{array}$ & $\begin{array}{l}-63.148^{* *} \\
(29.415)\end{array}$ \\
\hline Race $=$ Black & $\begin{array}{l}-43.461^{* * *} \\
(11.727)\end{array}$ & $\begin{array}{l}-29.748^{* * * *} \\
(10.675)\end{array}$ & $\begin{array}{l}-28.558^{* * *} \\
(10.067)\end{array}$ & $\begin{array}{l}-29.628^{* *} \\
(12.523)\end{array}$ & $\begin{array}{l}-28.283^{* * *} \\
(10.016)\end{array}$ & $\begin{array}{l}-28.379^{* *} \\
(12.651)\end{array}$ \\
\hline Race $=$ Hispanic & $\begin{array}{c}-22.030 * \\
(12.725)\end{array}$ & $\begin{array}{c}-11.244 \\
(11.590)\end{array}$ & $\begin{array}{c}-11.970 \\
(12.243)\end{array}$ & $\begin{array}{c}-20.432 \\
(14.853)\end{array}$ & $\begin{array}{c}-10.136 \\
(12.484)\end{array}$ & $\begin{array}{c}-18.533 \\
(15.312)\end{array}$ \\
\hline Age & $\begin{array}{c}9.419 * \\
(5.259)\end{array}$ & $\begin{array}{c}6.076 \\
(4.223)\end{array}$ & $\begin{array}{c}1.554 \\
(5.178)\end{array}$ & $\begin{array}{c}0.806 \\
(7.747)\end{array}$ & $\begin{array}{c}1.825 \\
(5.177)\end{array}$ & $\begin{array}{c}0.994 \\
(7.836)\end{array}$ \\
\hline ASVAB score & & $\begin{array}{c}-123.139 \\
(161.425)\end{array}$ & $\begin{array}{c}-165.783 \\
(169.474)\end{array}$ & $\begin{array}{l}-221.081 \\
(213.330)\end{array}$ & $\begin{array}{c}-122.124 \\
(193.447)\end{array}$ & $\begin{array}{c}-163.900 \\
(250.781)\end{array}$ \\
\hline ASVAB score squared & & $\begin{array}{c}221.676 \\
(199.200)\end{array}$ & $\begin{array}{c}246.790 \\
(201.926)\end{array}$ & $\begin{array}{c}280.683 \\
(249.045)\end{array}$ & $\begin{array}{c}199.242 \\
(233.822)\end{array}$ & $\begin{array}{c}214.115 \\
(295.863)\end{array}$ \\
\hline GED & & & $\begin{array}{c}21.079 \\
(19.314)\end{array}$ & $\begin{array}{c}-5.849 \\
(28.303)\end{array}$ & $\begin{array}{c}19.165 \\
(19.412)\end{array}$ & $\begin{array}{c}-8.951 \\
(27.916)\end{array}$ \\
\hline High school diploma & & & $\begin{array}{c}31.952 * \\
(16.418)\end{array}$ & $\begin{array}{c}13.768 \\
(26.013)\end{array}$ & $\begin{array}{c}30.303^{*} \\
(16.406)\end{array}$ & $\begin{array}{c}10.782 \\
(25.711)\end{array}$ \\
\hline Associate college degree & & & $\begin{array}{c}140.774 \\
(103.715)\end{array}$ & $\begin{array}{c}151.562 \\
(114.438)\end{array}$ & $\begin{array}{c}139.333 \\
(102.905)\end{array}$ & $\begin{array}{c}149.241 \\
(111.290)\end{array}$ \\
\hline $\begin{array}{l}\text { Four-year college degree } \\
\text { or higher }\end{array}$ & & & $\begin{array}{c}38.241 \\
(35.914)\end{array}$ & $\begin{array}{c}29.132 \\
(55.290)\end{array}$ & & \\
\hline $\begin{array}{l}\text { Years worked in high-OTJ- } \\
\text { training occupations }\end{array}$ & & & & $\begin{array}{c}2.852 \\
(3.098)\end{array}$ & & $\begin{array}{c}4.351 \\
(3.455)\end{array}$ \\
\hline Constant & $\begin{array}{l}-188.667 \\
(149.058)\end{array}$ & $\begin{array}{c}-98.178 \\
(121.317)\end{array}$ & $\begin{array}{c}12.388 \\
(161.566)\end{array}$ & $\begin{array}{c}56.164 \\
(229.763) \\
\end{array}$ & $\begin{array}{c}-1.428 \\
(162.523) \\
\end{array}$ & $\begin{array}{c}38.667 \\
(234.264)\end{array}$ \\
\hline Mean value & 71.923 & 71.923 & 71.923 & 73.477 & 68.712 & 69.181 \\
\hline Observations & 709 & 709 & 709 & 543 & 657 & 498 \\
\hline$R^{2}$ & 0.021 & 0.045 & 0.064 & 0.074 & 0.060 & 0.072 \\
\hline
\end{tabular}

NOTE: Marginal effects; standard errors are in parentheses. ${ }^{*} p<0.10,{ }^{* *} p<0.05,{ }^{* * *} p<0.01$.

women generally do not earn significantly different wages from White women, while Hispanic women generally earn statistically significantly higher wages than White women. $\underline{3}$

Next we examine the effect of a juvenile conviction on the growth rate of wages in Tables 15 and 16 for men and women, respectively. Starting with the estimates in Column 1 of Table 15, for men, a juvenile conviction reduces the 10-year growth rate of wages by 40.7 percentage points and both the Black race dummy and the Hispanic race dummy have negative coefficients on wage growth. Once we control for the ability measures, the coefficients on the race dummies become statistically insignificant. The negative effects of a juvenile conviction on wage growth remain large and significant across all specifications. As seen in the table's most exhaustive specification (Column 4), a juvenile conviction reduces wage growth by 25.8 percentage points for men. The results for lesseducated male workers are reported in Columns 5 and 6 . The negative effects of a juvenile conviction are slightly larger in magnitude among this disadvantaged group. For them, as seen in Column 6 , 
a juvenile conviction leads to a 26.1-percentage-point reduction in wage growth. We also note that experience in high-OTJ-training occupations leads to higher wage growth (Columns 4 and 6).

Turning to the estimates in Table 16 for women, we find a juvenile conviction reduces wage growth by a larger magnitude for them than for men. In this table's most exhaustive specification (Column 4), we find that a juvenile conviction reduces wage growth by 66.4 percentage points for women. Compared with the average 10 -year wage growth for women, this estimate is very large. Column 6 shows that a juvenile conviction reduces wage growth by 63.1 percentage points for lesseducated female workers. The coefficients on experience in high-OTJ-training occupations are insignificant (Columns 4 and 6), while the coefficients on the Black race dummy remain negative and significant. Our findings here suggest an interesting gender difference in wage growth dynamics.

\subsection{Juvenile Conviction and Recidivism}

In Sections 4.1 to 4.4 we discussed the effects of a juvenile conviction on human capital investment and labor market outcomes. In this section, we investigate the relationship between a juvenile conviction and recidivism during adulthood. We find that individuals with a juvenile conviction are more likely to commit crimes in adulthood. As discussed in the conceptual framework, a higher probability of future recidivism reduces an individual's incentive to invest in human capital ex ante, which may help explain our estimated negative effects of a juvenile conviction on human capital investment.

Table 17 reports the estimates of the marginal effects of a juvenline conviction on the probability of adult incarceration using a logit model for men. It shows a positive and statistically significant impact for all specifications. As shown in Column 1, among men, a juvenile conviction increases the probability of adult incarceration by 3.5 percentage points, after controlling for race and age. As we sequentially add the ability and education measures, the estimated effects become 2.7 percentage points and 1.4 percentage points, respectively. In the table's most exhaustive specification (Column 4), where measures of work experience are added, the probability of adult male incarceration increases by 0.9 percentage points. We also investigate the effects for less-educated men and find a much larger effect (1.4-percentage-point increase). It is also worth noting that once we control for the work-experience measures, the coefficient of the Black race dummy is not statistically significant (Columns 4 and 6), suggesting that employment dynamics hold the key for understanding the racial differences in crime behavior.

Table 18 reports the results of the same analysis for women. The effect of a juvenile conviction on the probability of adult incarceration becomes smaller once we control for test scores; adding education further reduces the effect on incarceration by half (Column 3). Focusing on Column 4, adding work experience and experience in high-OTJ-training occupations, the effect of juvenile conviction on the probability of adult incarceration becomes small and statistically insignificant; in addition, we find a statistically significant negative coefficient in front of the variable for experience in high-OTJ-training occupations. Columns 5 and 6 report the analysis for women without a four-year college degree or higher and show a statistically significant positive impact of a juvenile conviction on the incarceration probability of women with lower education. Overall the results confirm the relationship between juvenile conviction and future incarceration, highlighting the importance of education and work experience in reducing this probability. Our analysis is suggestive, but these relationships can be also driven by unobserved traits and skills of individuals who have higher educational attainment and work experience, especially in high-OTJ-training occupations. 
Table 17

The Effects of a Juvenile Conviction on Adult Male Incarceration

\begin{tabular}{|c|c|c|c|c|c|c|}
\hline & (1) & $(2)$ & (3) & (4) & (5) & (6) \\
\hline Juvenile conviction & $\begin{array}{l}0.0351^{* * *} \\
(0.00401)\end{array}$ & $\begin{array}{l}0.0274^{* * *} \\
(0.00353)\end{array}$ & $\begin{array}{l}0.0139 * * * \\
(0.00290)\end{array}$ & $\begin{array}{l}0.0094^{* * *} \\
(0.00200)\end{array}$ & $\begin{array}{l}0.0218^{* * *} \\
(0.00450)\end{array}$ & $\begin{array}{l}0.0142^{* * * *} \\
(0.00297)\end{array}$ \\
\hline Race $=$ Black & $\begin{array}{l}0.0200^{* * *} \\
(0.00336)\end{array}$ & $\begin{array}{l}0.0095^{* * * *} \\
(0.00350)\end{array}$ & $\begin{array}{r}0.0066^{* *} \\
(0.00269)\end{array}$ & $\begin{array}{c}0.0022 \\
(0.00182)\end{array}$ & $\begin{array}{r}0.0103 * * \\
(0.00422)\end{array}$ & $\begin{array}{l}0.0031 \\
(0.00278)\end{array}$ \\
\hline Race $=$ Hispanic & $\begin{array}{c}0.0015 \\
(0.00407)\end{array}$ & $\begin{array}{l}-0.0045 \\
(0.00369)\end{array}$ & $\begin{array}{l}-0.0032 \\
(0.00272)\end{array}$ & $\begin{array}{l}-0.0017 \\
(0.00181)\end{array}$ & $\begin{array}{l}-0.0054 \\
(0.00437)\end{array}$ & $\begin{array}{l}-0.0030 \\
(0.00280)\end{array}$ \\
\hline Age & $\begin{array}{c}0.0000 \\
(0.00026)\end{array}$ & $\begin{array}{c}0.0002 \\
(0.00022)\end{array}$ & $\begin{array}{c}0.0002 \\
(0.00016)\end{array}$ & $\begin{array}{c}0.0006^{*} \\
(0.00032)\end{array}$ & $\begin{array}{c}0.0003 \\
(0.00026)\end{array}$ & $\begin{array}{c}0.0009^{*} \\
(0.00050)\end{array}$ \\
\hline ASVAB score & & $\begin{array}{c}0.0103 \\
(0.01708)\end{array}$ & $\begin{array}{c}0.0156 \\
(0.01270)\end{array}$ & $\begin{array}{c}0.0046 \\
(0.00952)\end{array}$ & $\begin{array}{c}0.0281 \\
(0.02107)\end{array}$ & $\begin{array}{c}0.0099 \\
(0.01530)\end{array}$ \\
\hline ASVAB score squared & & $\begin{array}{l}-0.0533^{* * *} \\
(0.01945)\end{array}$ & $\begin{array}{r}-0.0334^{* *} \\
(0.01465)\end{array}$ & $\begin{array}{l}-0.0140 \\
(0.00975)\end{array}$ & $\begin{array}{r}-0.0587^{* *} \\
(0.02537)\end{array}$ & $\begin{array}{l}-0.0261 \\
(0.01658)\end{array}$ \\
\hline GED & & & $\begin{array}{c}0.0031 \\
(0.00262)\end{array}$ & $\begin{array}{l}-0.0006 \\
(0.00199)\end{array}$ & $\begin{array}{c}0.0050 \\
(0.00414)\end{array}$ & $\begin{array}{l}-0.0009 \\
(0.00303)\end{array}$ \\
\hline High school diploma & & & $\begin{array}{l}-0.0131^{* * *} \\
(0.00277)\end{array}$ & $\begin{array}{c}-0.0080^{* * * *} \\
(0.00189)\end{array}$ & $\begin{array}{c}-0.0207^{* * *} \\
(0.00415)\end{array}$ & $\begin{array}{c}-0.0120^{* * *} \\
(0.00272)\end{array}$ \\
\hline Associate college degree & & & $\begin{array}{l}-0.0318^{* * *} \\
(0.00797)\end{array}$ & $\begin{array}{l}-0.0219^{* * * *} \\
(0.00612)\end{array}$ & $\begin{array}{l}-0.0502^{* * *} \\
(0.01217)\end{array}$ & $\begin{array}{c}-0.0332^{* * *} \\
(0.00893)\end{array}$ \\
\hline $\begin{array}{l}\text { Four-year college degree } \\
\text { or higher }\end{array}$ & & & $\begin{array}{l}-0.0359 * * * \\
(0.00551)\end{array}$ & $\begin{array}{l}-0.0229 * * * \\
(0.00407)\end{array}$ & & \\
\hline Years worked & & & & $\begin{array}{l}-0.0010^{*} \\
(0.00056)\end{array}$ & & $\begin{array}{l}-0.0017^{*} \\
(0.00088)\end{array}$ \\
\hline Years worked squared & & & & $\begin{array}{l}-0.0000 \\
(0.00004)\end{array}$ & & $\begin{array}{l}-0.0000 \\
(0.00006)\end{array}$ \\
\hline $\begin{array}{l}\text { Years worked in high-OTJ- } \\
\text { training occupations }\end{array}$ & & & & $\begin{array}{l}-0.0002 \\
(0.00039)\end{array}$ & & $\begin{array}{l}-0.0004 \\
(0.00060)\end{array}$ \\
\hline Mean value & 0.030 & 0.030 & 0.030 & 0.017 & 0.035 & 0.021 \\
\hline Observations & 26,878 & 26,878 & 26,878 & 19,981 & 22,633 & 16,076 \\
\hline Pseudo $R^{2}$ & 0.059 & 0.085 & 0.132 & 0.129 & 0.103 & 0.106 \\
\hline
\end{tabular}

Aizer and Doyle (2015) also produce large recidivism estimates, finding that juvenile incarceration increases the probability of being incarcerated as an adult by age 25 by 23 percentage points. They go on to show that individuals who experience juvenile incarceration are more likely to recidivate for serious crimes including homicide, violence, and drug offenses. This finding suggests there is a behavioral change due to juvenile incarceration, which may be watered down in our sample since we include all convicted juveniles, of which only about 23 percent are incarcerated in the Aizer and Doyles (2015) sample. 
Table 18

The Effects of a Juvenile Conviction on Adult Female Incarceration

\begin{tabular}{|c|c|c|c|c|c|c|}
\hline & (1) & $(2)$ & (3) & (4) & (5) & (6) \\
\hline Juvenile conviction & $\begin{array}{c}0.0098^{* * * *} \\
(0.00201)\end{array}$ & $\begin{array}{l}0.0077^{* * *} \\
(0.00204)\end{array}$ & $\begin{array}{r}0.0035^{* *} \\
(0.00158)\end{array}$ & $\begin{array}{c}0.0017 \\
(0.00103)\end{array}$ & $\begin{array}{l}0.0086^{* * *} \\
(0.00327)\end{array}$ & $\begin{array}{r}0.0042^{* *} \\
(0.00213)\end{array}$ \\
\hline Race $=$ Black & $\begin{array}{c}0.0012 \\
(0.00154)\end{array}$ & $\begin{array}{c}-0.0010 \\
(0.00160)\end{array}$ & $\begin{array}{l}-0.0003 \\
(0.00090)\end{array}$ & $\begin{array}{c}-0.0015^{*} \\
(0.00088)\end{array}$ & $\begin{array}{l}-0.0006 \\
(0.00219)\end{array}$ & $\begin{array}{c}-0.0037^{*} \\
(0.00190)\end{array}$ \\
\hline Race $=$ Hispanic & $\begin{array}{c}0.0008 \\
(0.00189)\end{array}$ & $\begin{array}{c}-0.0007 \\
(0.00175)\end{array}$ & $\begin{array}{c}-0.0002 \\
(0.00099)\end{array}$ & $\begin{array}{l}-0.0006 \\
(0.00076)\end{array}$ & $\begin{array}{l}-0.0005 \\
(0.00242)\end{array}$ & $\begin{array}{c}-0.0016 \\
(0.00189)\end{array}$ \\
\hline Age & $\begin{array}{c}0.0000 \\
(0.00013)\end{array}$ & $\begin{array}{c}0.0001 \\
(0.00011)\end{array}$ & $\begin{array}{c}0.0001 \\
(0.00008)\end{array}$ & $\begin{array}{c}0.0002 \\
(0.00012)\end{array}$ & $\begin{array}{c}0.0002 \\
(0.00018)\end{array}$ & $\begin{array}{c}0.0005 \\
(0.00031)\end{array}$ \\
\hline ASVAB score & & $\begin{array}{c}-0.0062 \\
(0.00775)\end{array}$ & $\begin{array}{l}-0.0002 \\
(0.00414)\end{array}$ & $\begin{array}{l}-0.0005 \\
(0.00405)\end{array}$ & $\begin{array}{c}0.0015 \\
(0.01023)\end{array}$ & $\begin{array}{c}0.0020 \\
(0.01078)\end{array}$ \\
\hline ASVAB score squared & & $\begin{array}{l}-0.0027 \\
(0.00784)\end{array}$ & $\begin{array}{l}-0.0007 \\
(0.00432)\end{array}$ & $\begin{array}{l}-0.0011 \\
(0.00455)\end{array}$ & $\begin{array}{l}-0.0046 \\
(0.01108)\end{array}$ & $\begin{array}{c}-0.0074 \\
(0.01342)\end{array}$ \\
\hline GED & & & $\begin{array}{l}-0.0013 \\
(0.00105)\end{array}$ & $\begin{array}{l}-0.0007 \\
(0.00093)\end{array}$ & $\begin{array}{l}-0.0032 \\
(0.00247)\end{array}$ & $\begin{array}{l}-0.0019 \\
(0.00238)\end{array}$ \\
\hline High school diploma & & & $\begin{array}{r}-0.0028^{* *} \\
(0.00128)\end{array}$ & $\begin{array}{l}-0.0013 \\
(0.00092)\end{array}$ & $\begin{array}{c}-0.0068^{* * *} \\
(0.00253)\end{array}$ & $\begin{array}{c}-0.0032^{*} \\
(0.00190)\end{array}$ \\
\hline Associate college degree & & & $\begin{array}{c}-0.0033^{*} \\
(0.00177)\end{array}$ & $\begin{array}{l}-0.0016 \\
(0.00140)\end{array}$ & $\begin{array}{r}-0.0079^{* *} \\
(0.00376)\end{array}$ & $\begin{array}{c}-0.0042 \\
(0.00334)\end{array}$ \\
\hline $\begin{array}{l}\text { Four-year college degree } \\
\text { or higher }\end{array}$ & & & $\begin{array}{l}-0.0100^{* * *} \\
(0.00185)\end{array}$ & $\begin{array}{l}-0.0055^{* * * *} \\
(0.00163)\end{array}$ & & \\
\hline Years worked & & & & $\begin{array}{l}-0.0001 \\
(0.00017)\end{array}$ & & $\begin{array}{l}-0.0005 \\
(0.00044)\end{array}$ \\
\hline Years worked squared & & & & $\begin{array}{l}0.0000 \\
(0.00001)\end{array}$ & & $\begin{array}{c}0.0000 \\
(0.00003)\end{array}$ \\
\hline $\begin{array}{l}\text { Years worked in high-OTJ- } \\
\text { training occupations }\end{array}$ & & & & $\begin{array}{l}-0.0003^{*} \\
(0.00015)\end{array}$ & & $\begin{array}{l}-0.0008^{*} \\
(0.00043)\end{array}$ \\
\hline Mean value & 0.006 & 0.006 & 0.006 & 0.003 & 0.007 & 0.005 \\
\hline Observations & 27,139 & 27,139 & 27,139 & 18,572 & 21,109 & 13,222 \\
\hline Pseudo $R^{2}$ & 0.042 & 0.062 & 0.101 & 0.104 & 0.062 & 0.067 \\
\hline
\end{tabular}

\section{CONCLUSION}

In this article, we show that juvenile conviction has a long-term impact on human capital accumulation, wages, and recidivism. Specifically, we find that individuals with a juvenile conviction have lower education levels, lower employment rates, and are less likely to work in occupations with high-OTJ-training requirements. Juvenile conviction reduces wages mainly through its negative impact on education and work experience (including both general experience and occupationspecific work experience). Regarding the effect on recidivism, we find that a juvenile conviction is associated with a higher probability of incarceration in adulthood. Finally, all these effects are more pronounced among individuals without a four-year college degree or higher. Our results highlight 
the rich dynamics and interplay between educational choices, occupational choices, employment, wages, and recidivism when analyzing the effects of a juvenile conviction. While we find negative effects of a juvenile conviction on long-term labor market outcomes as well as on the probability of adult incarceration, even after controlling for measures of ability and education, it is possible that some of the effects are due to unobserved traits and skills differences between individuals with a juvenile conviction and those without. To address this issue, including the interactions of juvenile convictions, individuals' traits and skills, and employers' discrimination, future analysis using a structural model to investigate these dynamic mechanisms and evaluate alternative policies is a fruitful direction.

\section{NOTES}

1 Much of the existing literature on crime and labor market focuses on the relationship between adult conviction or incarceration and labor market outcomes; see Prescott and Starr (2020), for example.

$\underline{2}$ See, for example, Gayle and Golan (2012) for a discussion on occupational sorting and discrimination.

$\underline{3}$ There are differences in the patterns of labor market attachment and labor supply of Black and White women, which is discussed in the literature.

\section{REFERENCES}

Aizer, Anna and Doyle, Joseph J., Jr. "Juvenile Incarceration, Human Capital, and Future Crime: Evidence from Randomly Assigned Judges." Quarterly Journal of Economics, May 2015, 130, pp. 759-803; https://doi.org/10.1093/qje/qjv003.

Apel, Robert and Sweeten, Gary. "The Impact of Incarceration on Employment During the Transition to Adulthood." Social Problems, 2010, 57, pp. 448-79; https://doi.org/10.1525/sp.2010.57.3.448.

Bayer, Patrick; Hjalmarsson, Randi and Pozen, David. "Building Criminal Capital Behind Bars: Peer Effects in Juvenile Corrections." Quarterly Journal of Economics, 2009, 124, pp. 105-47; https://doi.org/10.1162/qjec.2009.124.1.105.

Forrest, Christopher; Tambor, Ellen; Riley, A.; Ensminger, Margaret and Starfield, B. "The Health Profile of Incarcerated Male Youth." Pediatrics, 2000, 105, pp. 286-91.

Gayle, George-Levi and Golan, Limor. "Estimating a Dynamic Adverse-Selection Model: Labour-Force Experience and the Changing Gender Earnings Gap 1968-1997." Review of Economic Studies, 2012, 79, pp. 227-67; https://doi.org/10.1093/restud/rdr019.

Golan, Limor; James, Jonathan and Sanders, Carl. "What Explains the Racial Gaps in Task Assignment and Pay Over the Life-Cycle?" Society for Economic Dynamics, 2019.

Imai, Susumu and Krishna, Kala. "Employment, Deterrence, and Crime in a Dynamic Model." International Economic Review, 2004, 45, pp. 845-72; https://doi.org/10.1111/j.0020-6598.2004.00289.x.

Kashani, Javad H.; Manning, George W.; McKnew, Donald H.; Cytryn, Leon; Simonds, John F. and Wooderson, Phil C. "Depression Among Incarcerated Delinquents." Psychiatry Research, 1980, 3, pp. 185-91; https://doi.org/10.1016/0165-1781(80)90035-9.

Kirk, David S. and Sampson, Robert J. "Juvenile Arrest and Collateral Educational Damage in the Transition to Adulthood." Sociology of Education, 2013, 88, pp. 32-62; https://doi.org/10.1177/0038040712448862.

Levitt, Steven D. "Why Do Increased Arrest Rates Appear to Reduce Crime: Deterrence, Incapacitation, or Measurement Error?" Economic Inquiry, 1998, 36, pp. 353-72; https://doi.org/10.1111/j.1465-7295.1998.tb01720.x.

Litwok, Daniel. “Have You Ever Been Convicted of a Crime? The Effects of Juvenile Expungement on Crime, Educational, and Labor Market Outcomes" in Essays on the Economics of Juvenile Crime and Education, PhD dissertation. Michigan State University, 2015.

Lochner, Lance. "Education, Work, and Crime: A Human Capital Approach." International Economic Review, 2004, 45, pp. 811-43; https://doi.org/10.1111/j.0020-6598.2004.00288.x. 
Mancino, Maria Antonella; Navarro, Salvador and Rivers, David A. "Separating State Dependence, Experience, and Heterogeneity in a Model of Youth Crime and Education." Economics of Education Review, 2016, 54, pp. 274-305; https://doi.org/10.1016/j.econedurev.2016.07.005.

Merlo, Antonio and Wolpin, Kenneth I. "The Transition from School to Jail: Youth Crime and High School Completion Among Black Males." European Economic Review, 2015, 79, pp. 234-51; https://doi.org/10.1016/j.euroecorev.2015.07.015.

Nagin, Daniel S.; Farrington, David P. and Moffitt, Terrie E. "Life-Course Trajectories of Different Types of Offenders." Criminology, 1995, 33, pp. 111-39; https://doi.org/10.1111/j.1745-9125.1995.tb01173.x.

Nagin, Daniel S. and Land, Kenneth C. "Age, Criminal Careers, and Population Heterogeneity: Specification and Estimation of a Nonparametric, Mixed Poisson Model." Criminology, 1993, 31, pp. 327-62; https://doi.org/10.1111/j.1745-9125.1993.tb01133.x.

Nagin, Daniel S. and Paternoster, Raymond. "On the Relationship of Past to Future Participation in Delinquency." Criminology, 1991, 29, pp. 163-89; https://doi.org/10.1111/j.1745-9125.1991.tb01063.x.

Nagin, Daniel S. and Waldfogel, Joel. "The Effects of Criminality and Conviction on the Labor Market Status of Young British Offenders." International Review of Law and Economics, 1995, 15, pp. 109-26; https://doi.org/10.1016/0144-8188(94)00004-E.

Neal, Derek. "The Measured Black-White Wage Gap Among Women Is Too Small." Journal of Political Economy, 2004, 112, pp. S1-28; https://doi.org/10.1086/379940.

Paternoster, Raymond; Brame, Robert and Farrington, David P. “On the Relationship Between Adolescent and Adult Conviction Frequencies." Journal of Quantitative Criminology, 2001, 17, pp. 201-25; https://doi.org/10.1023/A:1011007016387.

Prescott, J.J. and Starr, Sonja B. "Expungement of Criminal Convictions: An Empirical Study." Harvard Law Review, June 2020; https://doi.org/10.2139/ssrn.3353620.

Ritter, Joseph A. and Taylor, Lowell J. "Racial Disparity in Unemployment." Review of Economics and Statistics, 2011, 93, pp. 30-42; https://doi.org/10.1162/REST a 00063.

Western, Bruce and Beckett, Katherine. "How Unregulated Is the U.S. Labor Market? The Penal System as a Labor Market Institution." American Journal of Sociology, 1999, 104, pp. 1030-60; https://doi.org/10.1086/210135.

Western, Bruce; Kling, Jeffrey and Weiman, David. "The Labor Market Consequences of Incarceration." Working Paper 829, Princeton University, Department of Economics, Industrial Relations Section, 2001. 